Article

\title{
Transcriptomics and Functional Analysis of Copper Stress Response in the Sulfate-Reducing Bacterium Desulfovibrio alaskensis G20
}

\author{
Abhilash Kumar Tripathi ${ }^{1,2,+}$, Priya Saxena ${ }^{1,3,+}$, Payal Thakur ${ }^{1,3}$, Shailabh Rauniyar ${ }^{1,2}$, Dipayan Samanta ${ }^{1,4}$, \\ Vinoj Gopalakrishnan ${ }^{1,3}$, Ram Nageena Singh 1,2 (D) and Rajesh Kumar Sani 1,2,3,4,5,*(D)
}

1 Department of Chemical and Biological Engineering, South Dakota School of Mines and Technology, Rapid City, SD 57701, USA; abhilashkumar.tripathi@mines.sdsmt.edu (A.K.T.); priya.saxena@mines.sdsmt.edu (P.S.); payal.thakur@mines.sdsmt.edu (P.T.); shailabh.rauniyar@mines.sdsmt.edu (S.R.); dipayan.samanta@mines.sdsmt.edu (D.S.); vinoj.gopalakrishnan@sdsmt.edu (V.G.); Ram.Singh@sdsmt.edu (R.N.S.)

2 2-Dimensional Materials for Biofilm Engineering, Science and Technology, South Dakota School of Mines and Technology, Rapid City, SD 57701, USA

3 Data Driven Material Discovery Center for Bioengineering Innovation, South Dakota School of Mines and Technology, Rapid City, SD 57701, USA

4 BuG ReMeDEE Consortium, South Dakota School of Mines and Technology, Rapid City, SD 57701, USA

5 Composite and Nanocomposite Advanced Manufacturing Centre-Biomaterials, Rapid City, SD 57701, USA

* Correspondence: Rajesh.Sani@sdsmt.edu

$\dagger$ These authors contributed equally to this work.

check for updates

Citation: Tripathi, A.K.; Saxena, P.; Thakur, P.; Rauniyar, S.; Samanta, D.; Gopalakrishnan, V.; Singh, R.N.; Sani, R.K. Transcriptomics and Functional Analysis of Copper Stress Response in the Sulfate-Reducing Bacterium Desulfovibrio alaskensis G20. Int. J. Mol. Sci. 2022, 23, 1396. https://doi.org/ $10.3390 /$ ijms 23031396

Academic Editor: Cheol-Won Yun

Received: 25 December 2021

Accepted: 24 January 2022

Published: 26 January 2022

Publisher's Note: MDPI stays neutral with regard to jurisdictional claims in published maps and institutional affiliations.

Copyright: (C) 2022 by the authors. Licensee MDPI, Basel, Switzerland. This article is an open access article distributed under the terms and conditions of the Creative Commons Attribution (CC BY) license (https:// creativecommons.org/licenses/by/ $4.0 /)$.

\begin{abstract}
Copper $(\mathrm{Cu})$ is an essential micronutrient required as a co-factor in the catalytic center of many enzymes. However, excess $\mathrm{Cu}$ can generate pleiotropic effects in the microbial cell. In addition, leaching of $\mathrm{Cu}$ from pipelines results in elevated $\mathrm{Cu}$ concentration in the environment, which is of public health concern. Sulfate-reducing bacteria (SRB) have been demonstrated to grow in toxic levels of $\mathrm{Cu}$. However, reports on $\mathrm{Cu}$ toxicity towards SRB have primarily focused on the degree of toxicity and subsequent elimination. Here, $\mathrm{Cu}$ (II) stress-related effects on a model SRB, Desulfovibrio alaskensis $\mathrm{G} 20$, is reported. $\mathrm{Cu}$ (II) stress effects were assessed as alterations in the transcriptome through RNA-Seq at varying $\mathrm{Cu}(\mathrm{II})$ concentrations $(5 \mu \mathrm{M}$ and $15 \mu \mathrm{M})$. In the pairwise comparison of control vs. $5 \mu \mathrm{M} \mathrm{Cu}(\mathrm{II}), 61.43 \%$ of genes were downregulated, and $38.57 \%$ were upregulated. In control vs. $15 \mu \mathrm{M} \mathrm{Cu}(\mathrm{II}), 49.51 \%$ of genes were downregulated, and $50.5 \%$ were upregulated. The results indicated that the expression of inorganic ion transporters and translation machinery was massively modulated. Moreover, changes in the expression of critical biological processes such as DNA transcription and signal transduction were observed at high $\mathrm{Cu}(\mathrm{II})$ concentrations. These results will help us better understand the $\mathrm{Cu}$ (II) stress-response mechanism and provide avenues for future research.
\end{abstract}

Keywords: Desulfovibrio alaskensis G20; sulfate reducing bacteria; RNA sequencing; transcriptomics; gene expression; copper; toxicity; oxidative stress; homeostasis; gene ontology

\section{Introduction}

Copper $(\mathrm{Cu})$ is a naturally available element used as a micronutrient by bacteria and is also an essential co-factor for many redox-active enzymes [1]. However, $\mathrm{Cu}$ is also an antimicrobial agent and results in progressive inhibition of bacterial growth with increasing concentration [2]. Due to its widespread presence in aquatic systems, $\mathrm{Cu}$ is deemed a pollutant instead of being crucial for cell metabolism and survival [1,3]. Copper originates from various sources (highway runoff, sludge dumping, mine tailings, and industrial effluents) worldwide [4]. It is reported at elevated levels in ground water and soil [5]. In addition, $\mathrm{Cu}$ has been the metal of choice for piping that is used in household water 
delivery systems [6]. However, the leaching of $\mathrm{Cu}$ from such distribution systems is a source of various illnesses (vomiting, diarrhea, liver damage, and kidney disease) and, therefore, a public health concern [7]. Surplus $\mathrm{Cu}$ in the environment generates distinctive pleiotropic effects in the bacterial cell. Such pleiotropic effects generate varying levels of stress responses that complement the copper homeostasis system in protecting the cell against $\mathrm{Cu}$ toxicity [1]. The interest in microbe-based bioremediation of heavy metals has surfaced in recent years as scientists and engineers try to remove, recover, or stabilize heavy metals in soils and aquatic systems [8]. Previous studies have described Cu homeostasis mechanism in other bacteria such as Escherichia coli, Pseudomonas aeruginosa, and Salmonella enterica [9-12]. Studies have suggested that the general mechanism of $\mathrm{Cu}$ homeostasis can be considered common in the bacterial kingdom [1,9].

Bacteria handle $\mathrm{Cu}$ stress through well-regulated $\mathrm{Cu}$ homeostasis components both intracellularly and extracellularly. However, no single pathway can account for a cell's $\mathrm{Cu}$ homeostasis profile, and several layers of gene regulation are needed towards $\mathrm{Cu}$ stress adaptation. Bacterial $\mathrm{Cu}$ homeostasis shows some distinctive characteristics where $\mathrm{Cu}$ exists in a chemical equilibrium between cupric $(\mathrm{Cu}(\mathrm{II}))$ and cuprous $(\mathrm{Cu}(\mathrm{I}))$ ions. These ions are readily complexed by various biological ligands as described in previous studies $[4,13,14] . \mathrm{Cu}(\mathrm{II})$ is present mainly in the oxidizing compartments (periplasm), while $\mathrm{Cu}(\mathrm{I})$ is prevalent in reducing compartments (cytoplasm) [1]. In general, $\mathrm{Cu}(\mathrm{II})$ is a relatively safe species and biologically more inert as compared to $\mathrm{Cu}(\mathrm{I})[9,11]$. $\mathrm{Cu}$ can cross the bacterial outer membrane into the periplasm through $\mathrm{Cu}(\mathrm{I}) / \mathrm{Cu}(\mathrm{II})$ porin ATPases $[1,15]$. However, to date, only a few $\mathrm{Cu}$ transporters have been validated, and all of them have different structures and transport mechanisms [12].

$\mathrm{Cu}$ and other heavy-metal toxicity in the environment have been addressed previously using sulfate-reducing bacteria (SRB) [4,16-18]. SRB are heterotrophic anaerobic microorganisms that oxidize simple organic compounds by reducing sulfate to sulfide [19]. The sulfide thus generated can easily remove heavy metals such as $\mathrm{Cu}$ from contaminated sites by forming metal sulfide complexes [16]. However, the mechanism of $\mathrm{Cu}$ homeostasis in SRB is unknown. Reports concerning the toxicity of $\mathrm{Cu}$ and other heavy metals towards SRB have primarily focused on their degree of toxicity and subsequent elimination [4,20-22]. Considering the importance of $\mathrm{Cu}$ in various industrial settings and its subsequent release and interaction with SRB in the environment, it is crucial to understand the genetic and molecular level mechanisms of $\mathrm{Cu}$ stress tolerance in SRB. In bacteria (both Gram-positive and Gram-negative), a highly regulated system of transcriptional regulators, soluble chaperones, membrane transporters, and cupro-proteins regulates $\mathrm{Cu}$ homeostasis $[10,23]$. These biomolecules maintain beneficial levels of $\mathrm{Cu}$ that vary, corresponding to different bacteria. Considering the changes induced at the genetic and molecular level during $\mathrm{Cu}$ stress, it is imperative to study genome-wide transcriptional changes during $\mathrm{Cu}$ stress. Such transcriptomic studies correlate genomic information to biological function and molecular pathways, which helps identify key gene regulation targets related to growth and stress adaptation. To the best of our knowledge, there is no report on transcriptomic analysis of any SRB under inhibitory $\mathrm{Cu}$ (II) concentration.

This study was aimed at measuring the bacterial transcriptional response to the exposure to sublethal levels of $\mathrm{Cu}$ (II) ions in a model SRB, Desulfovibrio alaskensis G20 (DA-G20). RNAsequencing technology was used to evaluate the expression pattern of multiple transcripts in DA-G20 exposed to $\mathrm{Cu}$ (II) ions. The bacterial response in terms of gene expression was further corelated to molecular functions and biological processes to understand the impact of $\mathrm{Cu}$ (II) stress on cellular pathways and molecular activities of gene products. The transcriptional response in DA-G20 was also compared with published transcriptional responses on other heavy metals to identify common and unique mechanisms of heavy metal stress tolerance. Overall, this study will enable the scientific community to obtain a more comprehensive picture of the biological processes impacted by $\mathrm{Cu}$ in other SRB species. 


\section{Results}

\subsection{DA-G20 Growth under Cu(II) Stress}

To generate a baseline for $\mathrm{Cu}(\mathrm{II})$ toxicity in DA-G20, growth characteristics and changes in cell morphology were studied. The growth rate decreased as the concentration of $\mathrm{Cu}(\mathrm{II})$ increased (Figure 1a). The best-fitting linear model was a polynomial curve with the best goodness of fit $\left(\mathrm{R}^{2}\right)$. The maximum specific growth rates $\left(\mu_{\max }\right)$ with $5 \mu \mathrm{M} \mathrm{Cu}(\mathrm{II})$ and $15 \mu \mathrm{M} \mathrm{Cu}(\mathrm{II})$ were found to be 0.13 and $0.10 \mathrm{~h}^{-1}$, respectively, compared to $0.17 \mathrm{~h}^{-1}$ for $\mathrm{Cu}(\mathrm{II})$ free control $(0 \mu \mathrm{M} \mathrm{Cu}(\mathrm{II}))$. The trend in $\mu_{\max }$ values indicates gradual inhibition in DA-G20 growth at high $\mathrm{Cu}(\mathrm{II})$ concentration. The growth profile of DA-G20 as a function of total cell protein was also studied in the presence of 0,5 , and $15 \mu \mathrm{M} \mathrm{Cu}$ (II) (Figure 1b). The results showed that with an increase in $\mathrm{Cu}$ (II) concentration, there is a significant decrease in total cell protein. It can be inferred from Figure $1 \mathrm{~b}$ that the toxicity of $\mathrm{Cu}(\mathrm{II})$ was dependent on the $\mathrm{Cu}$ (II) concentration in the media. The final total cell protein in the presence of $5 \mu \mathrm{M}$ and $15 \mu \mathrm{M} \mathrm{Cu}(\mathrm{II})$ was approximately $18.12 \%$ and $49.64 \%$ lower than $\mathrm{Cu}(\mathrm{II})$ free control, respectively. The inhibition of total cell protein at higher $\mathrm{Cu}$ (II) concentration resulted in longer lag times and lower growth rates, as discussed in a previous study [4]. As shown in Figure 1b, the cell protein concentration increased with time in $5 \mu \mathrm{M}$ and $15 \mu \mathrm{M}$ $\mathrm{Cu}$ (II) with almost similar lag times. The $\mathrm{t}_{1 / 2}$ (the time at which the total cell protein is half of the maximum total cell protein) was also calculated using a polynomial regression fit. The value of $t_{1 / 2}$ increased with increasing $\mathrm{Cu}$ (II) concentration. The $\mathrm{t}_{1 / 2}$ for $0 \mu \mathrm{M} \mathrm{Cu}$ (II) $(26.9 \mathrm{~h})$ was closer to the $\mathrm{t}_{1 / 2}$ of $5 \mu \mathrm{M}$ Cu(II) $(29.6 \mathrm{~h})$. However, at $15 \mu \mathrm{M} \mathrm{Cu}$ (II), the value of $t_{1 / 2}$ increased to $52 \mathrm{~h}$. In addition, scanning electron microscopy (SEM) was utilized to elucidate morphological changes in DA-G20 cells grown in varying concentrations of $\mathrm{Cu}(\mathrm{II})$ $(0,5$, and $15 \mu \mathrm{M} \mathrm{Cu}(\mathrm{II})$ ) (Figure 2). SEM analysis depicted a positive correlation between cell size and increasing $\mathrm{Cu}(\mathrm{II})$ concentration. The cell size increased as the concentration of $\mathrm{Cu}(\mathrm{II})$ was increased (Figure 2). Compared to $0 \mu \mathrm{M} \mathrm{Cu}(\mathrm{II})(2.538 \mu \mathrm{m})$, the cell size increased by $48 \%$ in $5 \mu \mathrm{M} \mathrm{Cu}(\mathrm{II})$ and $91.8 \%$ in $15 \mu \mathrm{M} \mathrm{Cu}(\mathrm{II})$. Additionally, spiral folds were also observed in cells grown in $5 \mu \mathrm{M} \mathrm{Cu}$ (II) and $15 \mu \mathrm{M} \mathrm{Cu}(\mathrm{II})$. The increase in cell size and presence of spiral folds might be due to pleiotropic effects generated by the presence of $\mathrm{Cu}(\mathrm{II})$ ions [24,25].

\subsection{Differential Gene Expression Analysis during Cu(II) Stress}

To explore potential molecular mechanisms of $\mathrm{Cu}(\mathrm{II})$ stress, global transcriptome analysis was performed on DA-G20 grown under varying concentrations of $\mathrm{Cu}(\mathrm{II})(0 \mu \mathrm{M}$, $5 \mu \mathrm{M}$, and $15 \mu \mathrm{M} \mathrm{Cu}(\mathrm{II})$ ). Differential gene expression (DGE) analysis was performed on samples collected from the control $(0 \mu \mathrm{M} \mathrm{Cu}(\mathrm{II}))$ and $\mathrm{Cu}(\mathrm{II})$ spiked samples $(5 \mu \mathrm{M}$ and $15 \mu \mathrm{M}$ $\mathrm{Cu}(\mathrm{II}))$. DeSeq2's median of ratios method was used for data normalization [26]. Pairwise transcriptome comparison between samples (SP1: $0 \mu \mathrm{M}$ vs. $5 \mu \mathrm{M} \mathrm{Cu}(\mathrm{II})$; SP2: $0 \mu \mathrm{M}$ vs. $15 \mu \mathrm{M} \mathrm{Cu}(\mathrm{II})$; SP3: $5 \mu \mathrm{M}$ vs. $15 \mu \mathrm{M} \mathrm{Cu}(\mathrm{II}))$ was performed to identify differentially expressed genes (DEGs) amongst the sample pairs. From here on, the various pairwise transcriptome analysis is referred to as: SP1 for $0 \mu \mathrm{M}$ vs. $5 \mu \mathrm{M} \mathrm{Cu}$ (II) comparison; SP2 for $0 \mu \mathrm{M}$ vs. $15 \mu \mathrm{M}$ $\mathrm{Cu}$ (II) comparison; SP3 for $5 \mu \mathrm{M}$ vs. $15 \mu \mathrm{M} \mathrm{Cu(II)} \mathrm{comparison.} \mathrm{DGE} \mathrm{analysis} \mathrm{after} \mathrm{median}$ of ratios normalization generated 1190, 1955, and 1144 genes with significant differential expression ( $p$-value $<0.05$ and $\mid \log _{2} \mathrm{FCl}>0$ ) in the pair-wise comparisons of SP1, SP2 and SP3, respectively (Figures $3 \mathrm{a}-\mathrm{C}$ and S1). In SP1, 61.43\% of genes were downregulated, and $38.57 \%$ of genes were upregulated, whereas in SP2, $49.51 \%$ of genes were downregulated, and $50.5 \%$ of genes were upregulated. The pairwise comparison of both copper spiked samples (SP3: $5 \mu \mathrm{M}$ vs. $15 \mu \mathrm{M} \mathrm{Cu}(\mathrm{II})$ ) resulted in $52.97 \%$ downregulated and $47.03 \%$ upregulated genes. A Venn diagram was implemented to understand the association between DEGs in SP1, SP2, and SP3 (Figure S2). SP1 and SP2 shared a total of 1000 genes in which 373 are commonly upregulated, 613 are commonly downregulated, and 14 are contra-regulated. Around $18.6 \%$ DEGs were significant ( $p$-value $<0.05$ ) only at high $\mathrm{Cu}(\mathrm{II})$ concentration (SP2). Correlation-based on $\log _{2} \mathrm{FC}$ between the common genes in SP1 and SP2 shows a Pearson correlation coefficient of 0.87 (Figure $3 \mathrm{~d}$ ). A strong correlation exists 
between the expression of common genes in SP1 and SP2. In SP1, 61.43\% of genes were downregulated, and $38.57 \%$ genes were upregulated ( $p$-value $<0.05$ ). Compared to SP1, $49.51 \%$ of genes were downregulated, and $50.5 \%$ of genes were upregulated in SP2. In SP3, $52.97 \%$ of genes were downregulated, and $47.02 \%$ were upregulated. A comprehensive table with protein names for all upregulated and downregulated genes in both SP1 and SP2 is given in Supplementary Information in Table S3. These results suggest that most DEGs were observed at high $\mathrm{Cu}$ (II) concentration (SP2), which might be due to increased $\mathrm{Cu}$ stress in bacteria. Table 1 below lists the top 10 significantly up- and downregulated genes in SP1 and SP2.

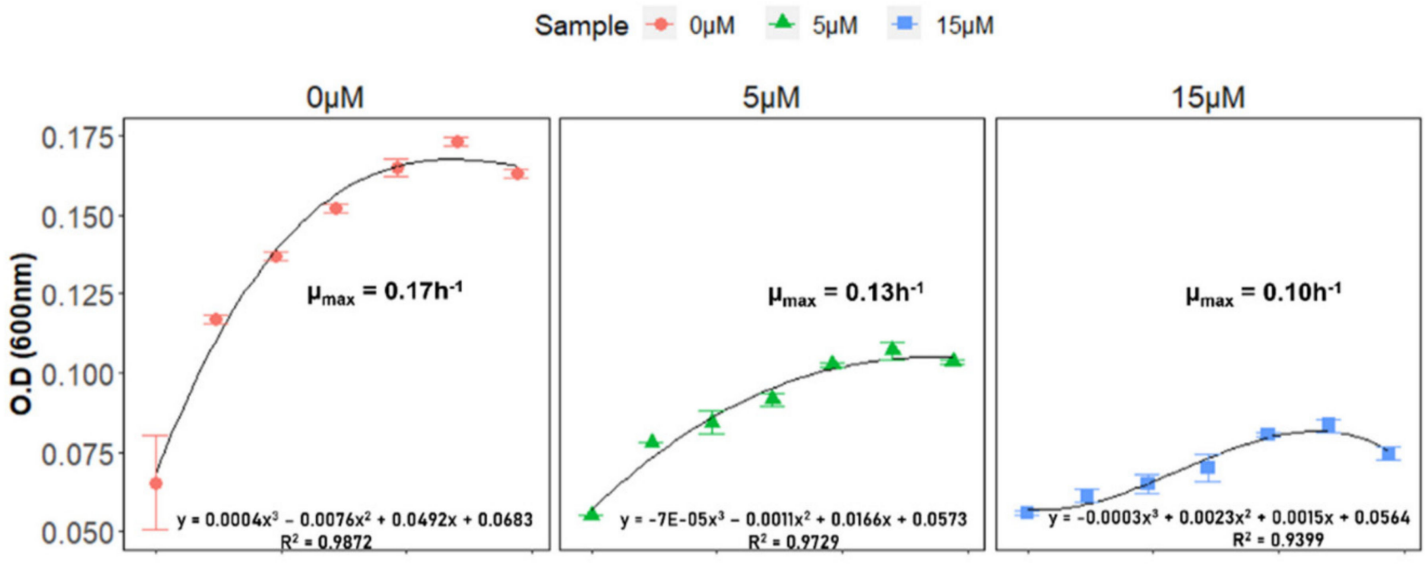

(a)

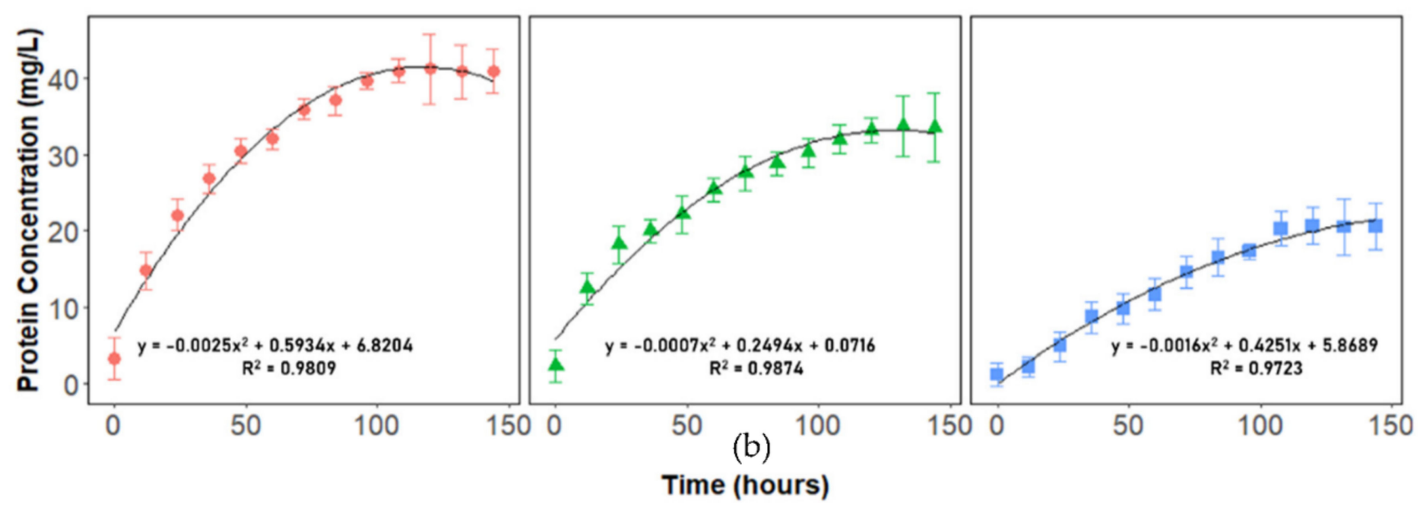

Figure 1. (a) Growth curve of DA-G20 in 0, 5, and $15 \mu \mathrm{M} \mathrm{Cu}(\mathrm{II})$; (b) Effect of $\mathrm{Cu}(\mathrm{II})$ on the growth DA-G20 as a function of total cell protein in presence of 0,5 and $15 \mu \mathrm{M} \mathrm{Cu}(\mathrm{II})$. The points for all samples are the average of triplicates, and error bars indicate \pm standard deviations of the means. Error bars smaller than the symbols are hidden behind sample legends. The best fit polynomial equation and goodness of fit $\left(\mathrm{R}^{2}\right)$ is shown corresponding to each plot.
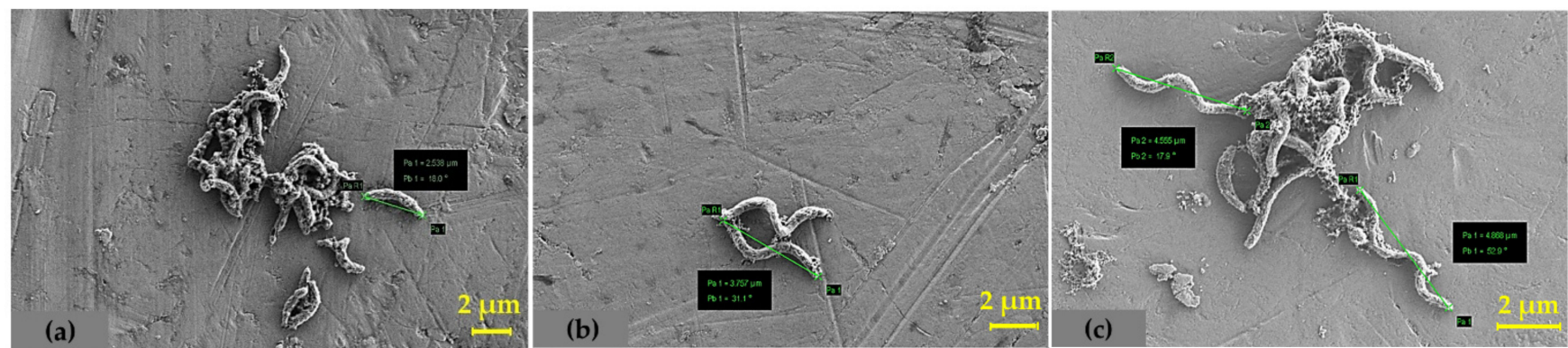

Figure 2. SEM image depicting variation in cell size of DA-G20 grown in media spiked with (a) $0 \mu \mathrm{M}$ $\mathrm{Cu}(\mathrm{II}),(\mathbf{b}) 5 \mu \mathrm{M} \mathrm{Cu}(\mathrm{II})$, and (c) $15 \mu \mathrm{M} \mathrm{Cu}(\mathrm{II})$. 


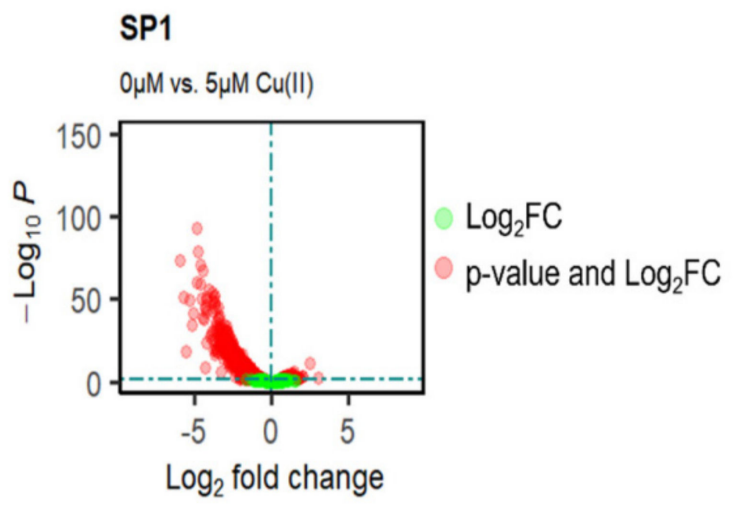

(a)

\section{SP3}

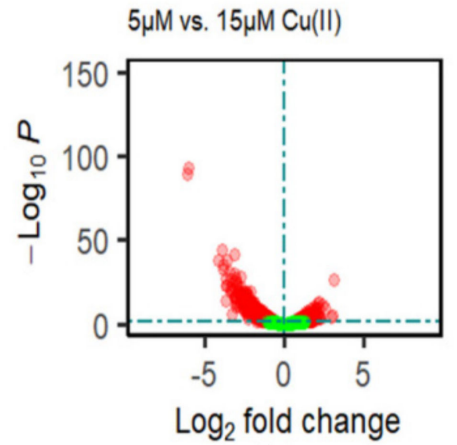

(c)

\section{SP2}

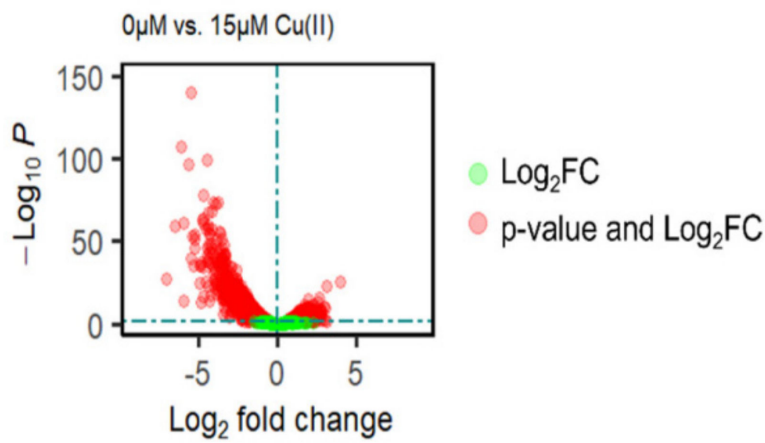

(b)

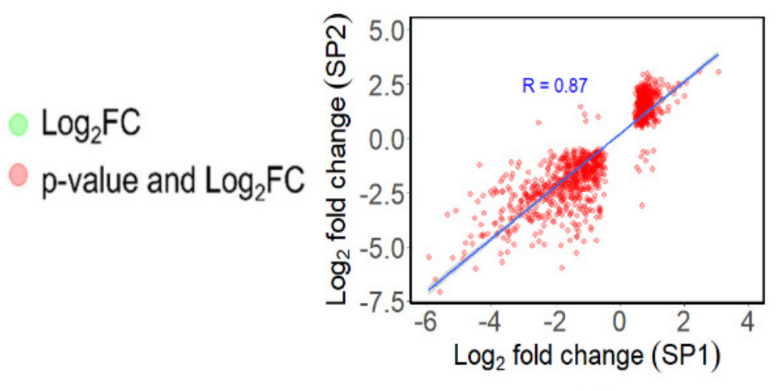

(d)

Figure 3. Differentially expressed genes in (a) SP1 (0 $\mu \mathrm{M}$ vs. $5 \mu \mathrm{M} \mathrm{Cu}(\mathrm{II}))$; (b) SP2 (0 $\mu \mathrm{M}$ vs. $15 \mu \mathrm{M}$ $\mathrm{Cu}(\mathrm{II}))$; (c) SP3 (5 $\mu \mathrm{M}$ vs. $15 \mu \mathrm{M} \mathrm{Cu}(\mathrm{II}))$; (d) Correlation between common genes in SP1 (0 $\mu \mathrm{M}$ vs. $5 \mu \mathrm{M} \mathrm{Cu}(\mathrm{II}))$ and SP2 $(0 \mu \mathrm{M}$ vs. $15 \mu \mathrm{M} \mathrm{Cu}(\mathrm{II}))$. Red dots are all significant ( $p$-value < 0.05) DEGs; Green dots are all insignificant genes with $\mid \log _{2} \mathrm{FCl}>0$.

Table 1. Top 10 upregulated and downregulated genes in SP1 $(0 \mu \mathrm{M}$ vs. $5 \mu \mathrm{M} \mathrm{Cu}(\mathrm{II}))$ and SP2 $(0 \mu \mathrm{M}$ vs. $15 \mu \mathrm{M} \mathrm{Cu}(\mathrm{II}))$.

\begin{tabular}{lccc}
\hline Gene ID & Protein Name & $\log _{2}$ FC & Standard Error \\
\hline Dde_2535* & ApbE family lipoprotein & 3.95 & \pm 0.37 \\
\hline Dde_2958* & Flagellar basal body rod protein & 3.12 & \pm 0.31 \\
\hline Dde_3047* & Protein serine/threonine phosphatase & 3.08 & \pm 1.19 \\
\hline Dde_1981* & Uncharacterized protein & 3.05 & \pm 0.93 \\
\hline Dde_0899* & Uncharacterized protein & 2.98 & \pm 0.48 \\
\hline Dde_1205* & Uncharacterized protein & 2.96 & \pm 0.44 \\
\hline Dde_2895* & Teichoic-acid-transporting ATPase & 2.85 & \pm 0.96 \\
\hline Dde_1929* & Uncharacterized protein & 2.82 & \pm 0.49 \\
\hline Dde_2799* & Phage regulatory protein, Rha family & 2.81 & \pm 0.63 \\
\hline Dde_0900* & RNA polymerase sigma factor, sigma-70 family & 2.77 & \pm 0.54 \\
\hline Dde_0111 & Zinc resistance-associated protein & -8.56 & \pm 0.30 \\
\hline
\end{tabular}


Table 1. Cont.

\begin{tabular}{|c|c|c|c|}
\hline Gene ID & Protein Name & $\log _{2} \mathrm{FC}$ & Standard Error \\
\hline Dde_4025 \# & Uncharacterized protein & -7.07 & \pm 0.64 \\
\hline Dde_2170 \# & UPF0235 protein Dde_2170 & -6.48 & \pm 0.39 \\
\hline Dde_2819 \# & Uncharacterized protein & -6.11 & \pm 0.27 \\
\hline Dde_3737 \# & Putative GAF sensor protein & -5.98 & \pm 0.77 \\
\hline Dde_2991 \# & $\begin{array}{l}\text { Transcription termination/antitermination } \\
\text { protein, NusG }\end{array}$ & -5.97 & \pm 0.36 \\
\hline Dde_3226" & Phage shock protein A, PspA & -5.68 & \pm 0.27 \\
\hline Dde_1010 \# & Uncharacterized protein & -5.52 & \pm 0.22 \\
\hline Dde_0221 \# & Response regulator receiver protein & -5.51 & \pm 0.41 \\
\hline Dde_0715 \# & Uncharacterized protein & -5.46 & \pm 0.35 \\
\hline Dde_3047** & Protein serine/threonine phosphatase & 3.05 & \pm 1.03 \\
\hline Dde_2958** & Flagellar basal body rod protein & 2.48 & \pm 0.36 \\
\hline Dde_0959** & AIG2 family protein & 2.04 & \pm 0.60 \\
\hline Dde_3729** & $\mathrm{ABC}$ transporter related protein & 2.01 & \pm 0.55 \\
\hline Dde_4035 ** & Uncharacterized protein & 1.87 & \pm 0.60 \\
\hline Dde_1264** & $\begin{array}{l}\text { PAS modulated sigma54 specific transcriptional } \\
\text { regulator, Fis family }\end{array}$ & 1.82 & \pm 0.67 \\
\hline Dde_3378 ** & Uncharacterized protein & 1.80 & \pm 0.61 \\
\hline Dde_0930 ** & Uncharacterized protein & 1.70 & \pm 0.53 \\
\hline Dde_3061 ** & M18 family aminopeptidase & 1.68 & \pm 0.69 \\
\hline Dde_0925 ** & Uncharacterized protein & 1.67 & \pm 0.62 \\
\hline Dde_0715 \#\# & Uncharacterized protein & -5.93 & \pm 0.32 \\
\hline Dde_2170 \#\# & UPF0235 protein Dde_2170 & -5.72 & \pm 0.37 \\
\hline Dde_4025 \#\# & Uncharacterized protein & -5.58 & \pm 0.63 \\
\hline Dde_0356 \#\# & Flagellar basal body rod protein FlgB & -5.34 & \pm 0.35 \\
\hline Dde_0221 \#\# & Response regulator receiver protein & -5.17 & \pm 0.42 \\
\hline Dde_0563 \#\# & Uncharacterized protein & -5.10 & \pm 0.37 \\
\hline Dde_1010 \#\# & Uncharacterized protein & -4.88 & \pm 0.23 \\
\hline Dde_2560 \#\# & Thioredoxin peroxidase & -4.84 & \pm 0.29 \\
\hline Dde_1689 \#\# & OmpA/MotB domain protein & -4.78 & \pm 0.25 \\
\hline Dde_0283 \#\# & Uncharacterized protein & -4.64 & \pm 0.26 \\
\hline
\end{tabular}

The most downregulated gene $\left(\log _{2} \mathrm{FC}=-8.56\right)$ in $\mathrm{SP} 2$ was zinc resistance-associated protein (ZraP (Dde_0111)). ZraP is a zinc-responsive periplasmic protein that binds $\mathrm{Cu}(\mathrm{II})$ with higher affinity than $\mathrm{Zn}(\mathrm{II})$ [27]. The downregulation of $\mathrm{zraP}$ in the presence of $15 \mu \mathrm{M}$ $\mathrm{Cu}$ (II) ions suggests a lower intake of $\mathrm{Cu}$ ions by DA-G20. zraP was also downregulated $\left(\log _{2} \mathrm{FC}=-2.42\right)$ in SP1, implicating a similar mechanism of $\mathrm{Cu}(\mathrm{II})$ stress tolerance. However, the most significantly upregulated $\left(\log _{2} \mathrm{FC}=3.05\right)$ gene, serine/threonine phosphatase (Dde_3047) in SP1 was also upregulated $\left(\log _{2} \mathrm{FC}=3.08\right)$ at the same level in SP2. In total, 373 genes were commonly upregulated between SP1 and SP2. However, the Pearson correlation coefficient $(\mathrm{R})$ between these 373 genes was 0.3378 , indicating a weak positive linear 
relationship between the shared upregulated genes. The R-value amongst the 613 commonly downregulated genes in SP1 and SP2 was 0.6017 , indicating a more positive linear relationship. In addition, several significantly up- and downregulated uncharacterized proteins were also identified, which could play an important part in imparting $\mathrm{Cu}$ toxicity tolerance in DA-G20 (Table 1 and Table S3). Finally, 15 genes were randomly selected for RT-qPCR validation of RNA-seq data. The expression pattern of the selected genes depicted the same expression trend as those detected by RNA-Seq, indicating good quality of the sequencing data (Figure S3).

\subsection{Gene Ontology Analyses of DEGs}

2.3.1. Biological Process, Molecular Function, and Cellular Component Enrichment Analyses

Gene ontology (GO) terms approximating biological process (BP), molecular functions $(\mathrm{MF})$, and cellular component (CC) were used for GO classification. BP represents pathways made up of the activities of multiple gene products; MF signifies molecular activities of gene products; $\mathrm{CC}$ represents the location of a protein relative to cellular compartments and structures. GO analysis was performed for all significantly upregulated and downregulated genes ( $p$-value $<0.05)$ in SP1 and SP2. The five most significantly enriched terms (BP, MF, CC) on the basis of total gene count in both SP1 and SP2 are given in Table 2.

Table 2. The top five most enriched GO terms with their respective $p$-values and z-score in both SP1 and SP2.

\begin{tabular}{|c|c|c|c|c|}
\hline \multicolumn{5}{|c|}{ Enriched GO Terms in SP1 (0 vs. $5 \mu \mathrm{M} \mathrm{Cu})$} \\
\hline Gene Ontology (GO) Term & GO ID & $\begin{array}{l}\text { Total Gene } \\
\text { Count }\end{array}$ & $\begin{array}{c}-\log _{10} \\
(p \text {-Value })\end{array}$ & z-Score * \\
\hline $\begin{array}{l}\text { Regulation of transcription, } \\
\text { DNA-templated (BP) }\end{array}$ & GO:0006355 & 34 & 16.5 & 0 \\
\hline $\begin{array}{l}\text { Phosphorelay signal } \\
\text { transduction system (BP) }\end{array}$ & GO:0000160 & 29 & 2.60 & -1.29 \\
\hline Translation $(\mathrm{BP})$ & GO:0006412 & 27 & 48.14 & -4.81 \\
\hline Chemotaxis (BP) & GO:0006935 & 19 & 2.74 & -2.98 \\
\hline Signal transduction (BP) & GO:0007165 & 18 & 2.73 & -1.88 \\
\hline ATP binding (MF) & GO:0005524 & 114 & 16.55 & 2.06 \\
\hline Metal ion binding (MF) & GO:0046872 & 97 & 2.97 & -2.94 \\
\hline Hydrolase activity (MF) & GO:0016787 & 54 & 1.96 & 0 \\
\hline $\begin{array}{l}4 \text { iron, } 4 \text { sulfur cluster } \\
\text { binding }(\mathrm{MF})\end{array}$ & GO:0051539 & 28 & 2.32 & -0.75 \\
\hline $\begin{array}{c}\text { ATPase-coupled } \\
\text { transmembrane transporter } \\
\text { activity (MF) }\end{array}$ & GO:0042626 & 25 & 1.64 & 3.40 \\
\hline $\begin{array}{l}\text { Integral component of } \\
\text { membrane }(C C)\end{array}$ & GO:0016021 & 212 & 3.38 & -0.41 \\
\hline Plasma membrane (CC) & GO:0005886 & 99 & 1.94 & -0.90 \\
\hline Cytoplasm (CC) & GO:0005737 & 76 & 1.77 & -2.52 \\
\hline $\begin{array}{l}\text { ATP-binding cassette (ABC) } \\
\text { transporter complex (CC) }\end{array}$ & GO:0043190 & 15 & 1.58 & 2.32 \\
\hline $\begin{array}{l}\text { Bacterial-type flagellum } \\
\text { basal body (CC) }\end{array}$ & GO:0009425 & 9 & 5.05 & -3.00 \\
\hline \multicolumn{5}{|c|}{ Enriched GO terms in SP2 (0 vs. $15 \mu \mathrm{M} \mathrm{Cu})$} \\
\hline Translation $(\mathrm{BP})$ & GO:0006412 & 54 & 51.75 & -7.07 \\
\hline $\begin{array}{l}\text { Regulation of transcription, } \\
\text { DNA-templated (BP) }\end{array}$ & GO:0006355 & 45 & 3.59 & 1.5 \\
\hline $\begin{array}{l}\text { Phosphorelay signal } \\
\text { transduction system (BP) }\end{array}$ & GO:0000160 & 45 & 2.30 & 0.15 \\
\hline
\end{tabular}


Table 2. Cont.

\begin{tabular}{|c|c|c|c|c|}
\hline \multicolumn{5}{|c|}{ Enriched GO Terms in SP1 (0 vs. $5 \mu \mathrm{M} \mathrm{Cu})$} \\
\hline Gene Ontology (GO) Term & GO ID & $\begin{array}{l}\text { Total Gene } \\
\text { Count }\end{array}$ & $\begin{array}{c}-\log _{10} \\
\text { (p-Value) }\end{array}$ & z-Score * \\
\hline Signal transduction (BP) & GO:0007165 & 22 & 5.76 & -0.85 \\
\hline Methylation (BP) & GO:0032259 & 20 & 4.26 & 0 \\
\hline ATP binding (MF) & GO:0005524 & 194 & 72.25 & 1.29 \\
\hline Metal ion binding (MF) & GO:0046872 & 152 & 3.30 & -1.13 \\
\hline Hydrolase activity (MF) & GO:0016787 & 81 & 4.37 & 1.22 \\
\hline $\begin{array}{c}\text { Transmembrane transporter } \\
\text { activity (MF) }\end{array}$ & GO:0022857 & 47 & 3.20 & 4.23 \\
\hline $\begin{array}{l}4 \text { iron, } 4 \text { sulfur cluster } \\
\text { binding (MF) }\end{array}$ & GO:0051539 & 42 & 2.33 & 0.3 \\
\hline $\begin{array}{l}\text { Integral component of } \\
\text { membrane }(C C)\end{array}$ & GO:0016021 & 346 & 17.47 & 4.3 \\
\hline Plasma membrane (CC) & GO:0005886 & 160 & 1.66 & 1.42 \\
\hline Cytoplasm (CC) & GO:0005737 & 149 & 1.52 & -5.65 \\
\hline $\begin{array}{l}\text { ATP-binding cassette }(\mathrm{ABC}) \\
\text { transporter complex }(\mathrm{CC})\end{array}$ & GO:0043190 & 34 & 1.73 & 4.11 \\
\hline $\begin{array}{l}\text { Bacterial-type flagellum } \\
\text { basal body (CC) }\end{array}$ & GO:0009425 & 6 & 2.76 & -0.81 \\
\hline
\end{tabular}

BP analysis revealed that the five most significantly enriched terms ( $p$-value $<0.05)$ in SP1 were (i) regulation of transcription DNA-templated (GO:0006355), (ii) phosphorelay signal transduction system (GO:0000160), (iii) translation (GO:0006412), (iv) chemotaxis (GO:0006935), and (v) signal transduction (GO:0007165). Compared to SP1, the five most significantly enriched BP terms in SP2 were (i) translation (GO:0006412), (ii) regulation of transcription DNA-templated (GO:0006355), (iii) phosphorelay signal transduction system (GO:0000160), (iv) signal transduction (GO:0007165), and (v) methylation (GO:0032259). BP enrichment indicates that translation was significantly impacted when the concentration of $\mathrm{Cu}$ (II) was increased to $15 \mu \mathrm{M}$. Interestingly, methylation was also enriched in SP2, which implies methylation might play a crucial role in gene regulation during high $\mathrm{Cu}$ (II) stress in DA-G20 [28]. With regard to MF, the three most enriched terms in SP1 and SP2 were the same (ATP binding (GO:0005524), metal ion binding (GO:0046872), and hydrolase activity (GO:0016787)). The fourth and fifth most enriched terms in SP1 were 4 iron, 4 sulfur cluster binding (GO:0051539), and ATPase-coupled cation transmembrane transporter activity (GO:0022857), and 4 iron, 4 sulfur cluster binding (GO:0051539). The enrichment of metal ion binding (GO:0046872) in both samples (SP1 and SP2) suggests the involvement of molecular machinery involved in binding $\mathrm{Cu}$ (II) ions. In addition, the enrichment in ATP binding activity demonstrates that DA-G20 requires more energy in translocating heavy-metal ions using ATPase coupled transmembrane transporter activity. The top three CC enriched terms in SP1 and SP2 were integral component of membrane (GO:0016021), plasma membrane (GO:0005886), and cytoplasm (GO:0005737). The fourth and fifth most enriched terms in SP1 and SP2 were ATP-binding cassette (ABC) transporter complex (GO:0043190) and bacterial-type flagellum basal body (GO:0009425). The CC enrichment analysis touts the involvement of proteins belonging to permease, transporter, and various membrane-bound cytochrome families. These protein families help to maintain metal homeostasis in a diverse group of bacteria [29].

Bubble plots showing gene counts of all GO enriched terms in SP1 and SP2 are depicted in Figure $4 a, b$, respectively. Furthermore, the number of up- and downregulated genes for each GO enriched term is provided in Figure S4. Interestingly, the highest number of downregulated genes in both samples was associated with translation (GO:0006412), 
indicating lower turnover of protein during heavy-metal stress. Regulation of transcription, DNA-templated (GO:0006355), had more upregulated genes in SP2 (z-score $=1.5)$, whereas it had a similar number of upregulated and downregulated genes in SP1 (z-score $=0)$. With respect to CC, the most drastic difference between SP1 and SP2 was observed for integral component of membrane (GO:0016021). The z-score (Table 2) pertaining to GO:0016021 for SP1 was -0.41 , whereas for SP2 it was 4.3 . The overexpression of genes related to GO:0016021 in SP2 indicates that most transporter proteins were upregulated at high $\mathrm{Cu}(\mathrm{II})$ concentrations. Genes involved in ATP-binding cassette (ABC) transporter complex were overexpressed in both SP1 (z-score $=2.32)$ and SP2 $(z$-score $=4.12)$. The metal ion binding activity relatively increased in SP2 (z-score $=-1.13)$ as compared to SP1 (z-score $=-2.94)$. Interestingly, there was no difference in the expression level of chemotaxis-related genes in both SP1 and SP2 (z-score = -2.98). A comprehensive table showing gene names and the associated GO terms (BP and MF) for both SP1 and SP2 is given in Table S4.

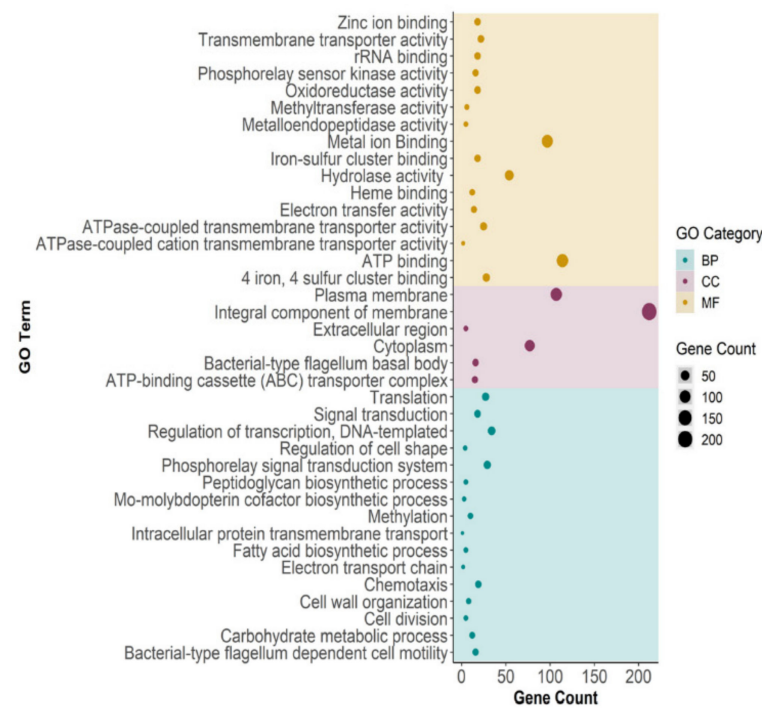

(a)

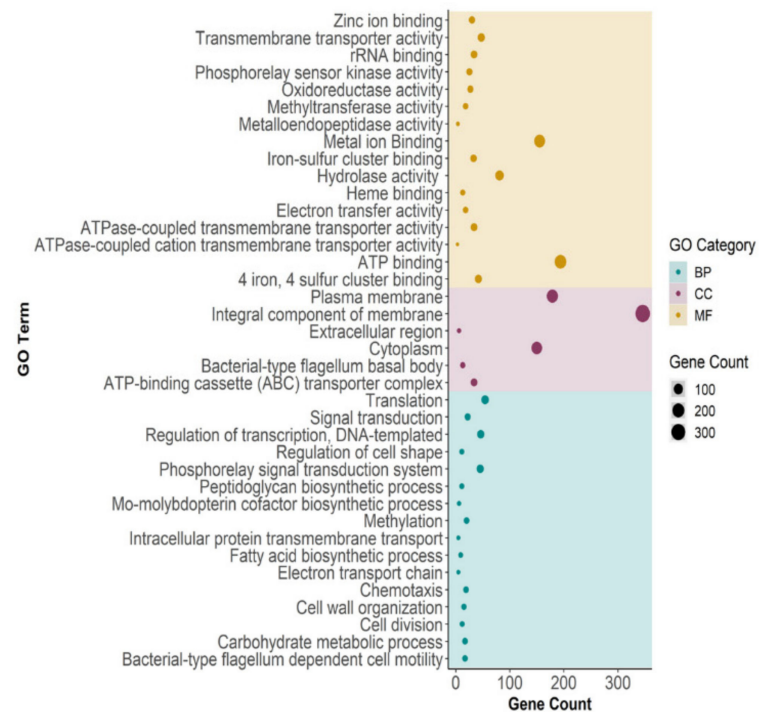

(b)

Figure 4. Bubble plot depicting gene counts of enriched GO terms in (a) $0 \mu \mathrm{M}$ vs. $5 \mu \mathrm{M} \mathrm{Cu}$ (II); (b) $0 \mu \mathrm{M}$ vs. $15 \mu \mathrm{M} \mathrm{Cu}(\mathrm{II})$. BP-Biological process; $\mathrm{CC}$-Cellular component; $\mathrm{MF}$-Molecular function.

\subsubsection{Association between Genes and Enriched GO Terms}

A comprehensive relationship between DGE and enriched GO functional categories (BP, MF) was interpreted by drawing a chord diagram using the GOChord function in $\mathrm{R}$ programming language [30]. The chord diagram for BP (Figure 5a,b) was drawn when at least 2 GO terms were assigned to a gene and at least 5 genes were assigned to a GO term. In the case of MF (Figure $5 c, d$ ), the chord diagram was drawn when at least 3 GO terms were assigned to a gene and at least 5 genes were assigned to at least one GO term. In SP1, the maximum number of GO-BP terms (3 each) was assigned to genes Dde_2411 and Dde_0703. Both of these genes (Dde_2411 and Dde_0703) code for proteins: methyl-accepting chemotaxis sensory transducer with Cache sensor and Pas/Pac sensor, respectively, which are part of bacterial two-component signal transduction system [31]. The most upregulated gene with 3 GO terms assigned in SP2 was Dde_0543, which codes for the lipid transporter protein-lipid II flippase (MurJ), that maintains cell shape and integrity during environmental stress [32]. Two more genes (Dde_0992 and Dde_1946) coding for peptidoglycan glycosyltransferase and undecaprenyl-diphosphatase, respectively, were assigned to 3 GO terms and are involved in cell-wall organization and peptidoglycan biosynthesis. The increased functional enrichment of genes involved in biological processes related to cell-wall maintenance highlights the importance of maintaining cell-wall integrity during heavy-metal stress in DA-G20. The gene with the most GO-MF terms assigned and 
the greatest fold change in SP1 was Dde_3105, which codes for iron-chelate-transporting ATPase (Figure 5c). This protein belongs to the class translocase and is involved in the translocation of inorganic cations. In SP2, Dde_0673 (glycine betaine/L-proline ABC transporter, ATPase subunit) was the most upregulated gene with three GO-MF terms assigned. In both SP1 and SP2, the most upregulated genes (Figure 5c,d) were primarily assigned to 3 GO-MF terms (ATP binding, hydrolase activity, and ATPase-coupled transmembrane transporter activity). The enrichment of these $3 \mathrm{GO}$ terms indicates an enhanced need for energy in the form of ATP for the optimal functioning of enzymes involved in hydrolase and transmembrane transporter activity. Compared to SP2, the upregulation of genes associated with these 3 GO-MF enriched terms (ATP binding, hydrolase activity, and ATPase-coupled transmembrane transporter activity) was negligible $\left(\log _{2} \mathrm{FC} \leq 1\right)$ in SP1, alluding to the fact that $15 \mu \mathrm{M} \mathrm{Cu}(\mathrm{II})$ was toxic enough to elicit metabolic responses in DA-G20 to maintain metal homeostasis. In addition, maintaining the homeostasis of transition metal ions such as $\mathrm{Cu}$ is essential for many physiological and biochemical processes required for bacterial metabolic activity [10]. The increase in expression of xenobiotic-transporting ATPase (Dde_1601) in SP2 $\left(\log _{2} \mathrm{FC}=2.33\right)$ as compared to SP1 $\left(\log _{2} \mathrm{FC}=0.52\right)$ indicates the ability of DA-G20 to maintain metal homeostasis at high $\mathrm{Cu}(\mathrm{II})$ concentration.

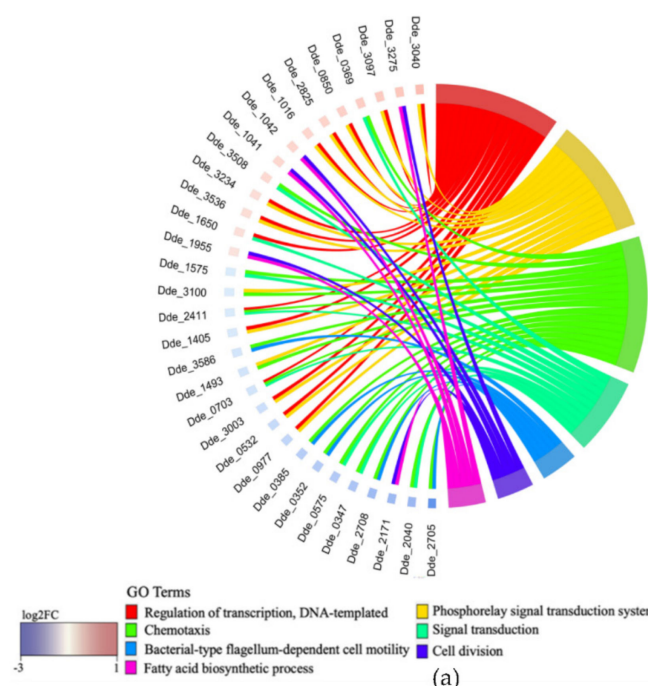

(a)

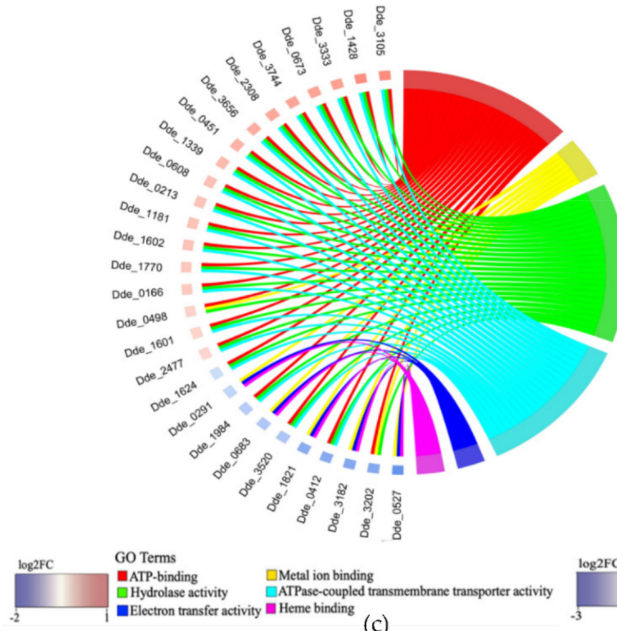

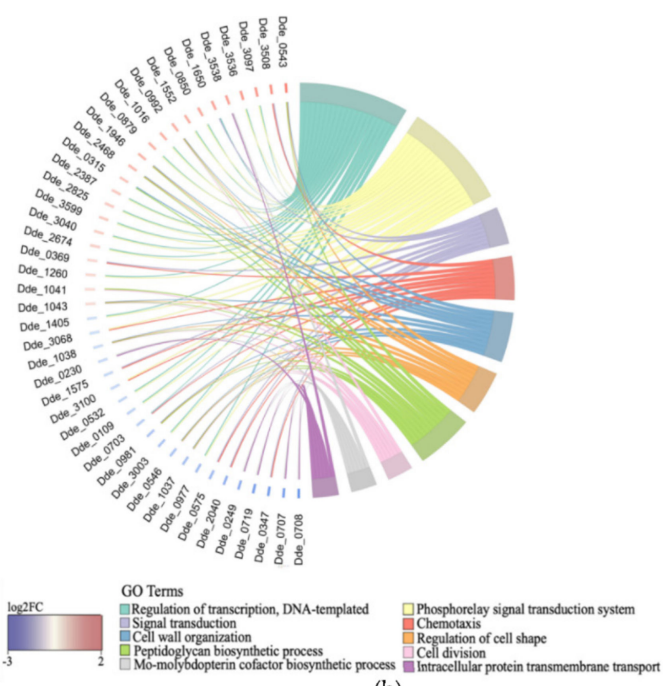

(b)

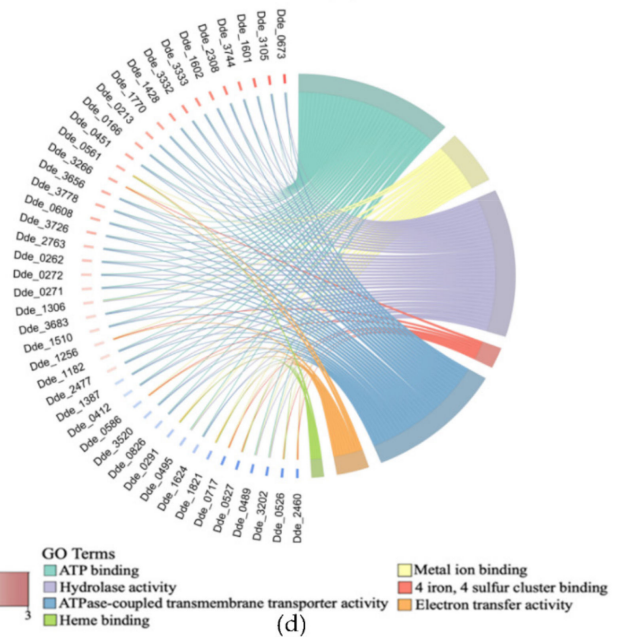

Figure 5. GOChord plot showing assignment of genes to their respective GO functional categories (BP and MF) according to their fold change in (a) SP1 (BP); (b) SP2 (BP); (c) SP1 (MF); (d) SP2 (MF). $\mathrm{BP}$-Biological process; MF-Molecular function. 


\subsubsection{Network Analysis of the DEGs and Identification of Clusters}

STRING database was used to identify potential interactions between DEGs in SP1 and SP2. A protein-protein interaction (PPI) network was drawn for both SP1 and SP2, and 6 clusters of highly interconnected nodes were identified. Figure 6 shows all the significant clusters found in the PPI network analysis of samples SP1 and SP2. The most significant cluster in SP1 was related to stress response and chaperone activity, whereas in SP2, the most significant cluster was related to translation, RNA metabolic process, and tRNA processing. Most of the genes in cluster 1 were downregulated in both SP1 and SP2. The second most significant cluster in SP1 was related to flagellar assembly and chemotaxis, whereas in SP2, it was related to chaperone activity and stress response. Stressresponse genes in SP2 were relatively upregulated as compared to SP1. Flagellar assembly and chemotaxis were combined into a single cluster (cluster 2) in SP1, whereas in SP2 flagellar assembly and chemotaxis were assigned into two different clusters (cluster 4 and cluster 5). However, a strong interaction between cluster 4 (flagellar assembly) and cluster 5 (chemotaxis) was seen in SP2, indicating co-regulation of genes involved in both processes. In SP1, the strongest inter-cluster correlation was between cluster 1 and cluster 4 , indicating the impact of $\mathrm{Cu}$ (II) stress on the expression of the iron-sulfur binding domain-containing proteins. A strong correlation between cluster 4 and cluster 3 was also observed in SP2, demonstrating the impact of signal transduction genes on chemotaxis during $\mathrm{Cu}$ (II) stress. Individual StringDB score for every interaction in all the clusters in both SP1 and SP2 is given in Table S5.

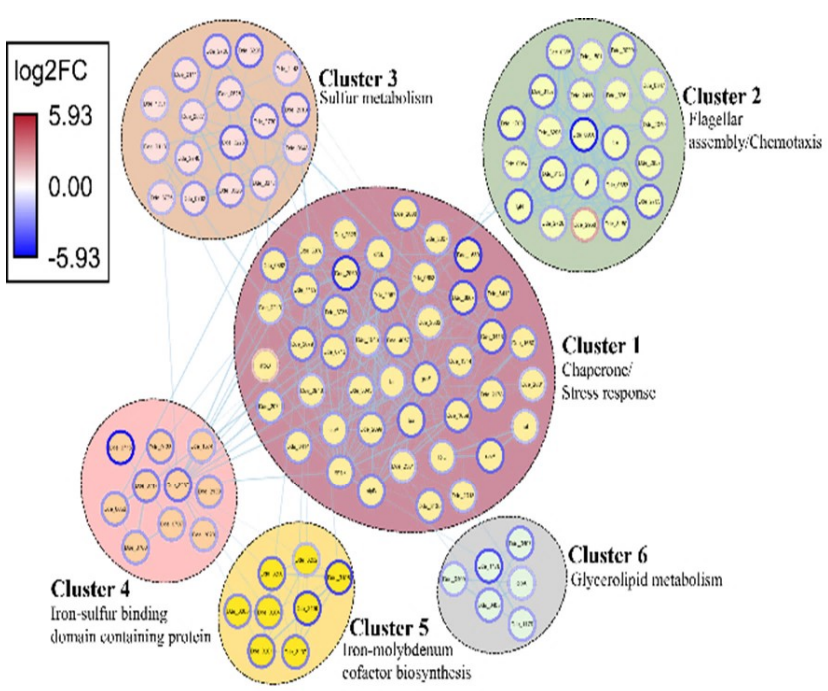

(a)

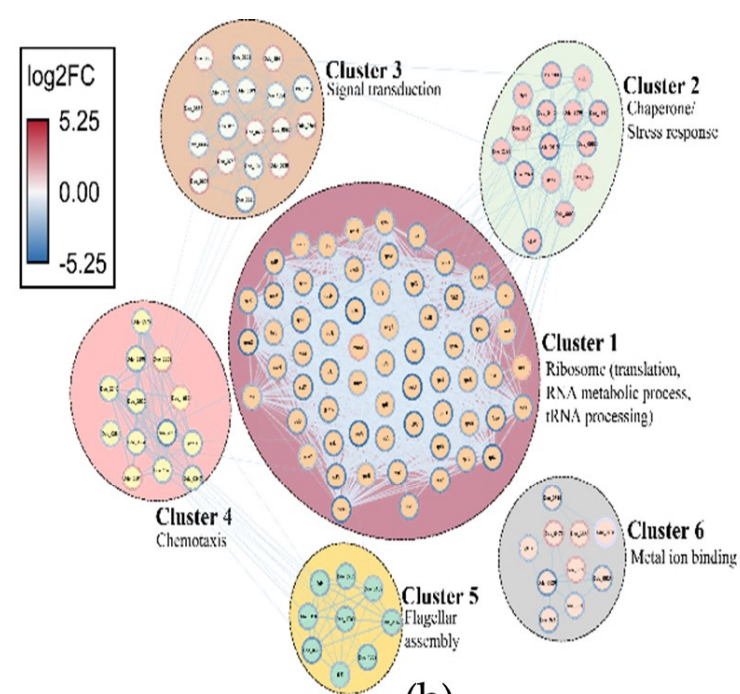

(b)

Figure 6. Protein-Protein interaction network in (a) $0 \mu \mathrm{M}$ vs. $5 \mu \mathrm{M} \mathrm{Cu}$ (II) (SP1), and (b) $0 \mu \mathrm{M}$ vs. $15 \mu \mathrm{M} \mathrm{Cu}$ (II) (SP2). Each cluster is a set of highly connected nodes and is illustrated in a circle.

\subsubsection{Metabolomic Profile of Control and Test Samples}

Targeted metabolomics analysis was carried out for all the samples $(0 \mu \mathrm{M}, 5 \mu \mathrm{M}$, and $15 \mu \mathrm{M} \mathrm{Cu}(\mathrm{II}))$. In total, 165 different intracellular and extracellular metabolites were identified in all the samples. Of these 165 metabolites, organic acids constituted 39.3\% of the compounds, and amino acids constituted $20.6 \%$ of the compounds. The rest of the metabolites constituted nucleotides, alcohols, amines, and lipids. The intracellular metabolite with the highest concentration in media spiked with $5 \mu \mathrm{M}$ and $15 \mu \mathrm{M} \mathrm{Cu}(\mathrm{II})$ was palmitic acid. Compared to control, the relative concentration of palmitic acid increased by approximately 7-fold and 3-fold in $5 \mu \mathrm{M}$ and $15 \mu \mathrm{M} \mathrm{Cu}$ (II), respectively. In the extracellular environment, the metabolite with highest concentration was lactic acid, whose relative concentration increased by approximately 193-fold in $5 \mu \mathrm{M} \mathrm{Cu}$ (II) and 522-fold in $15 \mu \mathrm{M}$ $\mathrm{Cu}$ (II). The increase in the concentration of lactic acid suggests that DA-G20 could not 
oxidize lactate in the presence of $\mathrm{Cu}(\mathrm{II})$ ions. Reduced lactate oxidation was also evident from downregulation $\left(\log _{2} \mathrm{FC}=-3.26\right)$ of lactate dehydrogenase (Dde_3239) in $15 \mu \mathrm{M}$ $\mathrm{Cu}(\mathrm{II})$. An increase in concentration of some specific amino acids was also observed in $5 \mu \mathrm{M}$ and $15 \mu \mathrm{M} \mathrm{Cu}(\mathrm{II})$ as compared to control. For example, in the extracellular environment, the amino acid with the highest concentration in $15 \mu \mathrm{M} \mathrm{Cu}$ (II) was pyroglutamic acid, while the intracellular amino acid with the highest concentration was alanine. However, the most interesting observation was the presence of ascorbic acid due to its involvement in the reduction of $\mathrm{Cu}(\mathrm{II})$ to $\mathrm{Cu}(\mathrm{I})$. The relative concentration of ascorbic acid increased with an increase in the concentration of $\mathrm{Cu}(\mathrm{II})$. Ascorbic acid was approximately 8-fold more in the presence of $15 \mu \mathrm{M} \mathrm{Cu}$ (II) as compared to control. Table S6 shows the concentration of all intracellular and extracellular metabolites observed in the presence of $0 \mu \mathrm{M}, 5 \mu \mathrm{M}$, and $15 \mu \mathrm{M} \mathrm{Cu}(\mathrm{II})$.

\section{Discussion}

Bacteria rapidly evolve countermeasures to resist heavy-metal stress through changes in gene expression and synthesis of specific molecules that alleviate toxicity $[33,34]$. While numerous studies have been conducted on understanding gene-level mechanisms towards heavy-metal stress in other bacteria, this study focused on a specific SRB (DA-G20). SRB are a diverse group of anaerobic bacteria that play an important role in the global cycling of carbon and sulfur [35]. In this study, RNA-Seq and metabolomics analysis was used to investigate the effect of $\mathrm{Cu}(\mathrm{II})$ stress on DA-G20 growth and differential gene expression. The key finding of this study is the establishment of transcriptional and metabolite alteration that occurs in DA-G20 in response to Cu(II) stress and the survival strategies used by DAG20 in the presence of $\mathrm{Cu}$ ions. The findings indicated that several $\mathrm{Cu}$-related stress effects in DA-G20 were comparable to the effects of other heavy-metal associated oxidative stress in many other groups of Gram-negative bacteria [36-39]. However, there were some unique effects that were not reported in previous studies conducted on heavy metals. For instance, the upregulation of ApbE family lipoprotein $\left(\log _{2} \mathrm{FC}=3.95\right)$ and modulation of methylation were not reported in past studies. DGE analysis showed that as compared to $5 \mu \mathrm{M} \mathrm{Cu}(\mathrm{II})$, media spiked with $15 \mu \mathrm{M} \mathrm{Cu}$ (II) had more DEGs. This indicates the ability of DA-G20 to adapt to increasing $\mathrm{Cu}(\mathrm{II})$ concentration by regulating gene expression. The data also revealed some uncharacterized DEGs that were significantly regulated in both SP1 and SP2. These uncharacterized proteins need to be classified as they probably play important roles in $\mathrm{Cu}$ stress tolerance in DA-G20. Some of the common transcriptional changes induced by $\mathrm{Cu}(\mathrm{II})$ ions are discussed in the following sections.

\subsection{Downregulation of Translation Machinery}

Most of the cellular ATP is used in the synthesis of proteins to carry out various biological processes and molecular functions [40]. The total downregulation of translation machinery in both SP1 and SP2 indicates that DA-G20 is saving most energy for stress response rather than translation. The same method of energy conservation was observed in previous studies conducted on other heavy metals. For instance, Joudeh et al. [36] reported that in the presence of palladium $(1 \mathrm{mM})$, there was complete downregulation of translation apparatus, including the expression of r-proteins and tRNA processing genes in E. coli K-12. Similarly, translation arrest and energy conservation were also reported in the presence of other heavy metals such as cadmium [41], nickel [42], and silver [43]. Most of the downregulated genes in translation encode for 30S and 50S ribosomal protein in both SP1 (92.5\% downregulated) and SP2 (96.3\% downregulated). The small subunit (30S) decodes genetic information delivered by mRNA, whereas the larger subunit (50S) synthesizes polypeptides from amino acids delivered by tRNAs [44]. This further corroborates that in the presence of $\mathrm{Cu}$ ions, DA-G20 cells save energy at the expense of translation. Translation was more suppressed in the presence of $15 \mu \mathrm{M} \mathrm{Cu}(\mathrm{z}$-score $=-7.07)$ than in the presence of $5 \mu \mathrm{M} \mathrm{Cu}(\mathrm{z}$-score $=-4.81)$, possibly due to more oxidative stress in SP2 (Table 2). 


\subsection{Modulation in Transporter Related Activity}

Transporters are essential for bacterial survival and growth as they are not only involved in the uptake of nutrients but also participate in defense mechanisms against environmental stress [45]. The most upregulated family of transporters in both SP1 and SP2 belonged to the ATP-Binding Cassette (ABC) superfamily of transporters. ABC is the largest protein transporter superfamily, and it consists of several proteins that are capable of transporting various inorganic and organic solutes across membranes [46,47]. The most upregulated ABC type transporter in SP2 was Dde_0611 (branched-chain amino acid transport system permease protein ( $\mathrm{LivH})$ ). In addition, other ABC-type amino acid transporters (Dde_0673, Dde_3743, Dde_1430) were also upregulated in SP2. These genes code for glycine/betaine/L-proline ABC transporter (Dde_0673) and polar amino acid ABC transporter (Dde_3743 and Dde_1430). The same amino acid ABC transporters (except Dde_1430) were also upregulated in SP1. The overexpression of ABC-type amino acid transporters suggests an osmotic upshift in the presence of $\mathrm{Cu}$ ions. Betaine and proline are osmotolerant molecules, and the upregulation of Dde_0673 (Glycine betaine/L-proline $\mathrm{ABC}$ transporter, ATPase subunit) could be one of the mechanisms of $\mathrm{Cu}$ stress regulation and maintenance of osmotic balance in DA-G20 [48,49]. The overexpression of these amino acid transporters may possibly help the cell to reverse the osmotic shrinkage of the cell and maintain cellular integrity [50]. However, certain ABC-type transporters (tungstate and molybdenum ABC transporter) were downregulated in both SP1 and SP2. The downregulation of tungstate and molybdenum $\mathrm{ABC}$ transporter was probably due to the downregulation of genes coding for proteins that require molybdenum and tungstate as co-factors. Interestingly, all ferrous iron (Fe(II)) transporter systems were downregulated in both SP1 and SP2. This clearly implies the disruption in Fe homeostasis in the presence of $\mathrm{Cu}$ and indicates that these systems could be more directly involved in $\mathrm{Cu}$ transport to the cell. The same downregulation trend was observed for Fe transporters in studies on other heavy-metal stress, including palladium [36], cobalt [51], mercury [52], and nickel [42].

In addition to $\mathrm{ABC}$ type transporters, transporters belonging to the resistance-nodulationcell division (RND)superfamily and heavy-metal translocating P-type ATPases were also modulated in both SP1 and SP2. ATPase-coupled transmembrane transporter proteins such as ATP-binding cassette $(\mathrm{ABC})$ transporters and P-type ATPases regulate the rate and mechanism of metal uptake and efflux [53]. The RND superfamily consists of seven protein families that are involved in the transport of heavy metals and hydrophobic compounds [54]. In this study, the RND efflux system genes were downregulated in both SP1 and SP2. Similarly, the heavy-metal translocating P-type ATPase genes were also downregulated. This observation is counterintuitive to results obtained on other heavy metals (cadmium and zinc) where the heavy-metal translocating P-type ATPases and heavy-metal RND genes were upregulated $[55,56]$. The downregulation of heavy-metal transporting ATPase was probably to maintain cellular homeostasis of $\mathrm{Cu}$ ions. One more plausible reason for this might be that metal ions antagonize metal uptake by inappropriately signaling sufficiency to transporters that are regulated allosterically [57]. A more detailed time-point study is required to elucidate temporal changes in the expression of these proteins. A previous study on $\mathrm{Cu}$ toxicity assessment in P. aeruginosa Q91147 observed that when bacterial cells attained an optimum level of intracellular $\mathrm{Cu}$ ions required for metabolic needs, the heavy-metal transporting ATPase was downregulated [58]. The downregulation of the RND efflux system in DA-G20 shows that it is probably highly sensitive to $\mathrm{Cu}$ ions. Similar results were observed for the RND efflux system, where its expression was induced in the presence of cadmium or zinc but not in the presence of cobalt [56]. However, for certain bacteria, $\mathrm{Cu}$ enters the cell via passive diffusion along its chemical gradient [1]. There is a possibility that $\mathrm{Cu}$ ions enter DA-G20 through passive diffusion since most of the heavy-metal translocating ATPases are downregulated. 


\subsection{Regulation of Oxidative Stress Response}

The results suggest an upregulation in the signal transduction pathways in SP2 as compared to SP1. The upregulation in signal transduction pathways might be due to increased oxidative stress in DA-G20 in the presence of high $\mathrm{Cu}$ (II) concentration. Metalinduced oxidative stress changes the redox state of the bacterial cell and impacts their ability to self-oxidation [36]. Generally, the reactive intermediates (mainly radicals) react with oxygen to form reactive oxygen species (ROS) such as superoxide anion $\left(\mathrm{O}_{2}{ }^{-}\right)$and hydrogen peroxide $\left(\mathrm{H}_{2} \mathrm{O}_{2}\right)$ [59]. However, $\mathrm{ROS}$ may also be generated by autooxidation of dehydrogenases, thiols, flavins, and oxidases [60]. ROS disrupts normal cellular function as they are implicated in severe damage to nucleic acids, lipids, and proteins [61]. In this study, upregulation in signal transduction pathways at high $\mathrm{Cu}$ (II) concentration was observed. Upregulation in signaling pathways was also observed in a study on the assessment of palladium toxicity in E. coli [36]. Apart from modulating the expression of signaling pathways, cytosolic buffering is another process through which bacteria limit oxidative damage caused by the sudden influx of metal ions [62]. In general, the cellular metal buffering system consists of small molecules (amino acids, glutathione, organic acids, inorganic ligands and weak ligands) on the surface of specific buffering proteins and a subset of delivery proteins [57]. GC-MS metabolite analysis showed increased concentration of some specific organic acids (2-Keto-L-gluconic acid, citric acid, glyceric acid, lactic acid, 2-methyl-2,3-dihydroxy propanoic acid, succinic acid, stearic acid) in the supernatant. The increased concentration of these organic acids in $15 \mu \mathrm{M} \mathrm{Cu}(\mathrm{II})$ implies inhibition in metabolization of these acids. The increased concentration of organic acids also indicates that they might play a role in the cellular metal buffering system. However, specific components of cellular metal buffering are starting to be elucidated and more research on the role of organic acids in cellular metal buffering is required. In addition to organic acids, bacteria use specific amino acids to prevent oxidative stress through cellular metal buffering [57]. The relative concentration of methionine significantly increased in the presence of $5 \mu \mathrm{M}$ $\mathrm{Cu}$ (II) and $15 \mu \mathrm{M} \mathrm{Cu}$ (II). Methionine is a sulfur-containing amino acid that forms the metal binding motif of many proteins and is involved in $\mathrm{Cu}$ (II) ion binding [63]. Many upregulated genes (including uncharacterized) in this study might code for proteins that have a methionine-rich motif and could be involved in $\mathrm{Cu}(\mathrm{II})$ ion binding. Similarly, a very high concentration of glycine, leucine, and isoleucine in the presence of $15 \mu \mathrm{M} \mathrm{Cu}(\mathrm{II})$ indicates upregulation of specific amino acid biosynthetic pathways during $\mathrm{Cu}$ (II) stress. However, in contrast to other studies, certain enzymes involved in removal of superoxide radicals were downregulated at high $\mathrm{Cu}$ (II) concentration (SP2). For example, superoxide dismutase (Dde_0882), thiol peroxidase (Dde_2313), and thioredoxin peroxidase were downregulated in the presence of $15 \mu \mathrm{M} \mathrm{Cu}(\mathrm{II})$. The genes coding for these enzymes were upregulated in studies on other heavy metals such as palladium and zinc $[36,64]$. These counterintuitive results suggests that DA-G20 might be using a completely different mechanism to counteract $\mathrm{Cu}$ (II) induced oxidative stress, and more research is required to elucidate the oxidative stress-tolerance mechanism in DA-G20. A starting point for deciphering the stress-response mechanism could be to check the activity of hydrolases. Hydrolase activity was significantly upregulated in the presence of $15 \mu \mathrm{M} \mathrm{Cu}(\mathrm{II})$ as compared to $5 \mu \mathrm{M}$ $\mathrm{Cu}$ (II). Studies have reported increased hydrolase activity and more integrated action of hydrolases during heavy-metal stress [65-67]. The upregulation in hydrolase activity in this study warrants more investigation into the role of hydrolases during $\mathrm{Cu}$ toxicity in DA-G20. 


\subsection{Impact on Chemotaxis and Signal Transduction System}

Chemotaxis is a process by which microorganisms sense and respond to changes in their environment through regulation in gene expression and/or active movement towards or away from a stimulus [68]. Bacterial chemotaxis involves chemosensory pathways, which are part of the two-component system (TCS) pathway signal transduction system [33]. In bacteria, the chemotaxis system consists of methyl-accepting chemotaxis proteins (MCPs), cytosolic chemotaxis proteins (Che proteins), and flagella. In this study, many genes coding for Che proteins (cheD, cheW, cheC, che Z) involved in the regulation of the signal transduction system were downregulated in both SP1 and SP2. However, the signal transduction pathways were comparatively more upregulated in SP2 as compared to SP1 (Table 2). In SP1, Dde_2411 and Dde_0703 were assigned the most GO-BP terms (Figure 5). Dde_2411 and Dde_0703 code for proteins that are involved in monitoring cation accumulation and regulating the expression of related metabolic responses to changes in the concentration of heavy-metal ions [69]. Chemotaxis-related proteins also regulate bacterial motility by regulating flagella behavior. The expression of flagella is regulated by the gradient of attractant or repellant substrate. When the cells sense an increase in concentration of attractants, the expression of flagella increases, and bacteria swim for longer times, whereas when they sense more repellants, the expression of flagella decreases [70]. Many flagella-related proteins were downregulated in both SP1 and SP2, indicating that $\mathrm{Cu}(\mathrm{II})$ acts as a heavy-metal repellant in DA-G20. The same phenomena of downregulation in cell motility-related proteins were observed in studies conducted on other heavy metals [71,72]. This indicates that reduction in cell motility and chemotaxis is a widespread mechanism in bacterial heavy-metal stress response. In addition to cell motility, another important component of the signal transduction pathway are the sigma $(\sigma)$ factors that provide tolerance towards heavy-metal stress by regulating the expression of outer membrane porins [73]. In this study, the gene (Dde_3097), which codes for PerARNT-Sim (PAS) domain $\sigma^{54}$ transcriptional regulator, was upregulated at high $\mathrm{Cu}$ (II) concentration (SP2). The upregulation in the phosphorelay signal transduction system facilitates activation of $\sigma^{54}$ through phosphorylation by a sensor-kinase protein [33]. In addition to the $\sigma^{54}$ transcriptional regulator, the RNA polymerase sigma factor $\left(\sigma^{70}\right)$ was also upregulated in $\mathrm{SP} 2 ; \sigma^{70}$ is involved in the transcription of genes that are essential for bacterial metabolism, growth, and stress responses [33]. The upregulation of $\sigma^{70}$ might be an adaptive response in DA-G20 to counteract $\mathrm{Cu}$ (II) toxicity and maintain optimal cellular metabolism and growth. Additionally, serine/threonine phosphatase (Dde_3047), which belongs to the two-component signaling system (TCS) was upregulated in both SP1 and SP2 at the same level $\left(\log _{2} \mathrm{FC} \approx 3\right)$. TCS is capable of phosphorylating response regulator $(\mathrm{RR})$ proteins to elicit appropriate cellular response in response to an environmental stimuli [74].

In summary, it was observed that $\mathrm{Cu}$ (II) stress response in DA-G20 shares certain commonalities when compared to other heavy-metal stress in different bacteria. Substantial difference demonstrated by differential regulation in certain biological processes and molecular functions related to stress response and transporter activity was also observed. However, certain unique transcriptional patterns were observed, which warrants further investigation into understanding $\mathrm{Cu}$ stress response in DA-G20. Some of these unique changes are discussed in brief in the following sections.

\subsection{Some Atypical Transcriptional Changes Induced by $\mathrm{Cu}$ (II) Ions}

Some transcriptional changes detected in this study were not observed or discussed in previous studies on heavy-metal stress. This section summarizes findings on such uncommon transcriptional changes. This section also discusses some counterintuitive results compared to other heavy-metal stress studies. 


\subsubsection{Significant Upregulation of ApbE Family Lipoprotein}

The most upregulated gene (15-fold) in SP2 was Dde_2535 (ApbE family lipoprotein). ApbE family lipoprotein is part of the ApbE superfamily and is a periplasmic lipoprotein anchored to the inner membrane [75]. The periplasmic ApbE lipoprotein has been implicated in thiamine biosynthesis [76], iron-sulfur cluster metabolism [77], and flavin transferase activity [78]. Interestingly, Dde_2535 was not significantly expressed ( $p$-value $>0.05$ ) in SP1 $(5 \mu \mathrm{M} \mathrm{Cu}(\mathrm{II}))$, implying that its activation was only triggered at high $\mathrm{Cu}(\mathrm{II})$ concentration. Dde_2535, therefore, might play an important role in Cu(II) stress tolerance in DA-G20. However, ApbE proteins are relatively understudied biochemically, and more targeted studies involving gene-knockout and $\mathrm{Cu}(\mathrm{II})$ stress response in the mutant could explain more about the role of $\mathrm{ApbE}$ proteins in $\mathrm{Cu}$ (II) tolerance in DA-G20.

\subsubsection{Differential Expression of DNA Repair Genes}

Heavy-metal-induced oxidative stress generates ROS, causing damage to many cellular components, including DNA and proteins [37]. In this study, eleven DNA repair enzymes were upregulated, and six were downregulated at high $(15 \mu \mathrm{M}) \mathrm{Cu}(\mathrm{II})$ concentration (SP2). At low $(5 \mu \mathrm{M}) \mathrm{Cu}(\mathrm{II})$ concentration (SP2), seven DNA repair enzymes were upregulated, and five were downregulated (Table S4). Previous studies have observed modulation in the expression of DNA repair genes in the presence of specific heavy metals. For example, upregulation in DNA repair genes was observed in the case of mercury, cadmium, zinc, and arsenic $[52,65,79,80]$. However, palladium exposure resulted in the downregulation of DNA repair genes [36], and no change in the expression pattern of DNA repair genes was observed in the case of nickel, copper, and cobalt [39,42,51]. In this study, specific DNA repair genes were both upregulated and downregulated at $15 \mu \mathrm{M} \mathrm{Cu}$ (II) concentration. Dde_2324 was 3.5-fold $\left(\log _{2} \mathrm{FC}=1.83\right)$ upregulated in SP2 as compared to SP1. Dde_2324 codes for the protein resolvase $(r u v C)$, which is a specialized nuclease that removes Holliday junctions (HJs) during DNA repair [81]. HJs are cross-stranded four-way junction structures formed during homologous recombination. These structures are detrimental to cell viability and must be removed in a timely manner to maintain genetic stability [82]. Modulation in the expression of ruvC to the best of our knowledge was not reported before in any heavy-metal stress study. The upregulation of ruvC in SP2 suggests that removal of $\mathrm{HJs}$ is an essential component $\mathrm{Cu}$ (II) stress tolerance mechanism in DA-G20. However, more targeted transcriptomics studies, including gene knockout, are required to establish the exact role of $r u v C$ and other DNA repair genes during heavy-metal stress.

\subsubsection{Modulation of Methylation Related Activity}

Methylation in bacteria is used as a signal for the epigenetic control of DNA-protein interactions that control gene regulation [83]. DNA methylation also protects genome integrity in prokaryotes [84]. This study showed an upregulation of ten methyltransferase coding genes at high $(15 \mu \mathrm{M}) \mathrm{Cu}$ (II) concentration. In contrast, at low $(5 \mu \mathrm{M}) \mathrm{Cu}$ (II) concentration, only one methyltransferase gene was upregulated. Upregulation of methyltransferases at high $\mathrm{Cu}$ (II) concentration indicates that methylation probably changes expression patterns of daughter cells based on environmental conditions [85]. The most upregulated methylation associated gene was Dde_2875 (methyltransferase FkbM family). To the best of our knowledge, modulation in the genes related to methylation was not reported before in any heavy metal or oxidative stress study. The reason for such modulation is probably related to gene regulation associated with environmental adaptations. However, the exact mechanism of regulation is not known and provides avenues for future research.

\subsubsection{Regulation of Genes Associated with Cell Division and Cell Wall Organization}

Some genes involved in biological processes such as cell division, cell-wall organization, and cell cycle appeared to be both downregulated and upregulated. In SP2, 24 genes associated with these biological processes were differentially expressed, whereas in SP1, only 12 were differentially regulated. The most upregulated gene $\left(\log _{2} \mathrm{FC}=2.11\right)$ in SP2 


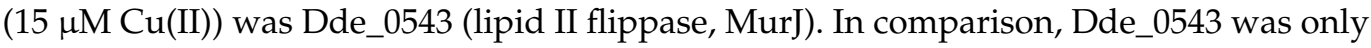
slightly modulated $\left(\log _{2} \mathrm{FC}=0.68\right)$ in SP1 $(5 \mu \mathrm{M} \mathrm{Cu}(\mathrm{II}))$. Lipid II flippase is essential in the regulation of cell shape and maintenance of cellular integrity during environmental stress. Depletion of MurJ causes cells to swell and burst, and as such, the overexpression of gene coding this protein seems to be essential during $\mathrm{Cu}$ (II) stress in DA-G20 [86]. An intriguing observation was the downregulation of an uncharacterized protein (Dde_0980) in both SP1 $\left(\log _{2} \mathrm{FC}=-1.78\right)$ and SP2 $\left(\log _{2} \mathrm{FC}=-2.79\right)$. The GO analysis indicated that this uncharacterized protein is involved in two biological processes: (i) cell septum assembly and (ii) FtsZ-dependent cytokinesis. FtsZ is a major cytoskeletal protein that initiates cell division in a bacterial cell [87]. Previous studies have shown that downregulation in ftsZ expression results in a transient delay in cell division that leads to an increase in cell size $[88,89]$. Another captivating observation was the downregulation of Dde_2171 in both SP1 $\left(\log _{2} \mathrm{FC}=-1.88\right)$ and SP2 $\left(\log _{2} \mathrm{FC}=-2.52\right)$. Dde_2171 codes for DivIVA domain-containing protein, which is a cell division initiation protein. Stationary phase or slow-growing cells have DivIVA at both cell poles; however, actively growing cells reduce the DivIVA concentration at the old poles and redeploy DivIVA molecules to build DivIVA rings at active division sites [90]. The downregulation of the DivIVA gene is probably an indication of slow growth and an increase in cell size at high $\mathrm{Cu}$ (II) concentration. In addition, the downregulation of divIVA might be explained by the poor health status of the bacterial cells that favor the downregulation of these genes in order to conserve energy for stress-related pathways. However, literature search showed that at present, there are no studies on the impact of heavy-metal stress on the DivIVA domain-containing protein. As such, the impact of heavy-metal stress on cell cycle, cell division, and cell shape is still poorly understood, and more research is required to better understand this impact. The impact of ftsZ and divIVA genes on cell size seems apparent; however, there is a possibility that mutations in some uncharacterized genes are responsible for generating pleiotropic effects that influence cell morphological characteristics, including cell size [25]. These observations suggest the need of genome-wide association studies that will shed more light on the contribution of some specific genes on observable phenotypic traits.

\subsubsection{Role of Ascorbic Acid and Alkaline Phosphatase}

The most important group of transporters during heavy-metal stress are copper influx and efflux proteins. Specific protein machineries are involved in fine-tuning the balance of intracellular copper trafficking and extracellular secretion according to cellular requirement [12]. However, the form of $\mathrm{Cu}$ ion $(\mathrm{Cu}(\mathrm{I})$ or $\mathrm{Cu}(\mathrm{II}))$ and the type of proteinimport system involved in copper trafficking inside the cell are debatable. For instance, Andrei et al. [23] implicated that the outer membrane porin OmpF is involved in the influx of $\mathrm{Cu}(\mathrm{II})$, whereas Giachino and Waldron [1] proposed that OmpF is involved in the influx of $\mathrm{Cu}(\mathrm{I})$ ions. In this study, it was observed that an increase in the concentration of ascorbic acid in the supernatant occurred when $\mathrm{Cu}$ (II) concentrations increased.Ascorbic acid is reported to be involved in the conversion of $\mathrm{Cu}$ (II) to $\mathrm{Cu}(\mathrm{I})$ [91]. The increase in expression of alkaline phosphatase (ALK) (Dde_1612) also corroborated the role of ascorbic acid in $\mathrm{Cu}$ (II) reduction as ALK hydrolyzes 2-phospho-Lascorbicacid (AAP) to generate ascorbic acid (AA) in the extracellular environment [91]. $\mathrm{Cu}(\mathrm{I})$ is relatively more toxic compared to $\mathrm{Cu}(\mathrm{II})$, and the reduction of $\mathrm{Cu}(\mathrm{II})$ to $\mathrm{Cu}$ (I) by ascorbic acid probably inhibits DA-G20 growth [1]. However, the mechanism of $\mathrm{Cu}(\mathrm{I})$ transport and growth inhibition in the presence of $\mathrm{Cu}(\mathrm{I})$ is still not clear. In addition to heavy-metal translocating P-type ATPases, $\mathrm{Cu}$ can also enter the cell via passive diffusion along its chemical gradient [1]. Based on the analysis of the metabolomics and RNA-seq data, a putative mechanism of $\mathrm{Cu}$ stress response in DA-G20 was devised and is presented in Figure 7. 


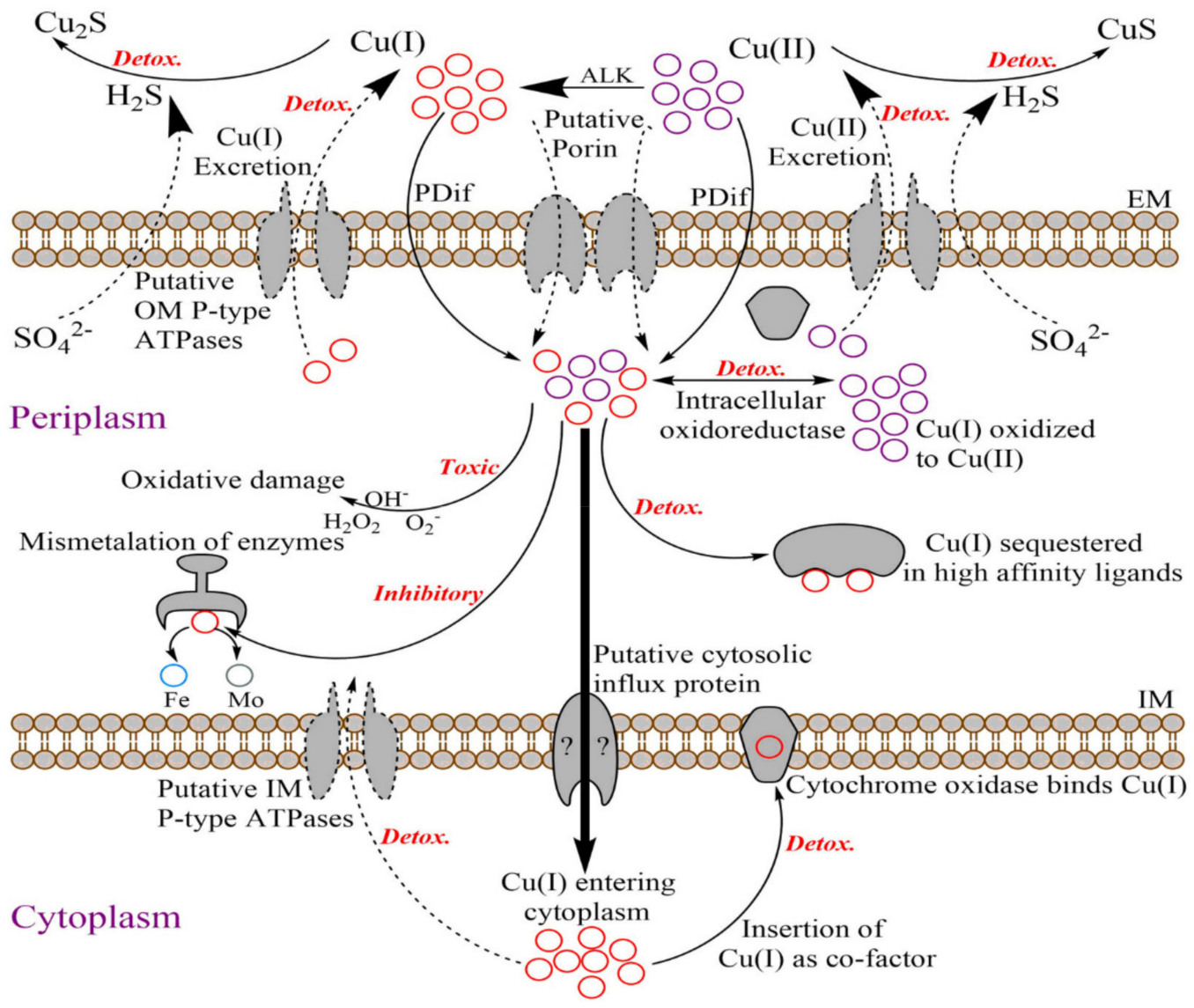

Figure 7. Schematic of putative copper transport and detoxification mechanism in Desulfovibrio vulgaris G20. ALK, Alkaline phosphatase; PDif, Passive diffusion; EM, Extracellular membrane; IM, Intracellular membrane; Detox., Detoxification mechanism.

\section{Materials and Methods}

\subsection{Bacterial Strain and Growth Conditions}

The bacterial strain used in this study was Desulfovibrio alaskensis strain G20 (DAG20). Lactate C medium (anoxic) was used to grow DA-G20 at $30^{\circ} \mathrm{C}$ and $125 \mathrm{rpm}$. The composition of the media is given in Table S1 in Supplementary Information. Medium $(100 \mathrm{~mL})$ was prepared in serum bottles and sterilized by autoclaving at $121^{\circ} \mathrm{C}$ for $15 \mathrm{~min}$. The medium was then deoxygenated by sparging filter-sterilized ultrapure nitrogen (10 psi) for $20 \mathrm{~min}$ as described previously [4,18].

\subsection{Copper Toxicity Experimental Setup}

Seed culture of strain DA-G20 was prepared by inoculating $1.5 \mathrm{~mL}$ of a frozen stock (40\% v/v glycerol stock solution and cells grown in lactate-C medium) into $100 \mathrm{~mL}$ of lactate$\mathrm{C}$ medium. The seed culture was incubated at $30{ }^{\circ} \mathrm{C}$ with an initial pH of 7.2 and $125 \mathrm{rpm}$. Hydrogen sulfide $\left(\mathrm{H}_{2} \mathrm{~S}\right)$ initially present in the active inoculum was purged out using filtersterilized ultrapure nitrogen for $1 \mathrm{~h}$. From this sparged culture, 5\% $v / v$ active inoculum $(\mathrm{OD}=0.18)$ was used for $\mathrm{Cu}(\mathrm{II})$ toxicity experiments. For $\mathrm{Cu}(\mathrm{II})$ toxicity experiments, filter-sterilized stock solution of $0.05 \mathrm{M} \mathrm{CuCl}_{2}$ was prepared and supplemented to serum bottles containing $100 \mathrm{~mL}$ lactate- $\mathrm{C}$ medium to give the desired metal concentrations ( $5 \mu \mathrm{M}$ and $15 \mu \mathrm{M}) . \mathrm{CuCl}_{2}$ dissociates into $\mathrm{Cu}(\mathrm{II})$ ions, and the $\mathrm{Cu}$ toxicity mentioned in this study refers to toxicity by $\mathrm{Cu}(\mathrm{II})$ ions. The maximum concentration was selected as $15 \mu \mathrm{M} \mathrm{Cu}(\mathrm{II})$ by preliminary experiments, since above this concentration, the growth rate reduced significantly, and the recovered RNA quantity was not sufficient for transcriptomic studies. Another reason for selecting $15 \mu \mathrm{M} \mathrm{Cu}$ (II) as the maximum concentration was 
approximately $50 \%$ inhibition in total cell protein at this concentration. The serum bottle containing no supplemented $\mathrm{Cu}$ (II) $(0 \mu \mathrm{M})$ was used as control for the experiment. All the experiments were carried out in triplicates for statistical validation.

\subsection{Determination of Total Cell Protein and SEM Analysis}

The total cell protein was estimated for each experimental condition $(0 \mu \mathrm{M} \mathrm{Cu}(\mathrm{II})$, $5 \mu \mathrm{M} \mathrm{Cu}(\mathrm{II}), 15 \mu \mathrm{M} \mathrm{Cu}(\mathrm{II})$ ) using a quantitative Coomassie (Bradford) protein assay kit (Thermo Fisher Scientific, Waltham, MA, USA). Protein concentrations were calculated by comparing the absorbance $(595 \mathrm{~nm})$ of all samples $(0 \mu \mathrm{M}, 5 \mu \mathrm{M}, 15 \mu \mathrm{M} \mathrm{Cu}(\mathrm{II}))$ to the color response of protein assay standards prepared as a series of known dilutions of bovine serum albumin (BSA). Polynomial regression was used to estimate the time at which total cell protein was half of the maximum cell protein. All the fit curves had $\mathrm{R}^{2}$ greater than 0.95 . The change in cell morphology (planktonic cells) was visualized using a field-emission scanning electron microscope (FESEM (Zeiss Supra40 variable pressure)). The samples for SEM were fixed by immersing in a mixture of $0.1 \mathrm{M}$ sodium cacodylate buffer and $2 \%$ glutaraldehyde overnight at $4{ }^{\circ} \mathrm{C}$ and then at room temperature for $1 \mathrm{~h}$. It was followed by sequential dehydration with ethanol (50\%, 75\%, 95\%, and 100\%) for $30 \mathrm{~min}$ each, followed by overnight drying in a desiccator. The SEM images were obtained using secondary electron imaging operated at an accelerated voltage of $1 \mathrm{kV}$.

\subsection{RNA Isolation}

Total RNA was extracted from $10 \mathrm{~mL}$ of bacterial culture from the serum bottles on the 5 th day from different $\mathrm{Cu}$ (II) concentrations. To pellet down the cells, $10 \mathrm{~mL}$ of the DA-G20 culture was taken out from the respective serum bottles and was centrifuged at $10,000 \times g$ for $10 \mathrm{~min}$ at $4{ }^{\circ} \mathrm{C}$. The cell pellet was collected and washed three times with anaerobic phosphate buffer saline ( $\mathrm{pH} 7.2)$ to remove any unwanted media components that may hamper RNA extraction. Cell pellet was then transferred to sterile $2 \mathrm{~mL}$ microcentrifuge tubes for further extraction steps. Total RNA was extracted using the TRIzol RNA extraction method and eluted in $20 \mu \mathrm{L}$ nuclease-free water [92]. Extracted RNA was further purified using the RNA clean and concentrator kit following the manufacturer's instructions (Zymo Research, Irvine, CA, USA) and eluted in $10 \mu \mathrm{L}$ nuclease-free water. RNA purity was assessed using Nanodrop UV-Vis spectrophotometer (Thermo Fisher Scientific, Waltham, MA, USA). The concentration was further evaluated using the Qubit RNA assay kit and Qubit 3.0 fluorometer (Thermo Fisher Scientific, Waltham, MA, USA). Finally, RNA integrity was assessed using the Bioanalyzer 2100 system (Agilent Technologies, Santa Clara, CA, USA).

\subsection{Complementary DNA (cDNA) Library Preparation and Sequencing}

Library preparation and RNA sequencing were performed by Oklahoma Medical Research Foundation NGS Core (Oklahoma city, OK, USA). The protocol contained the following steps: First, rRNA was depleted using RiboCop rRNA Depletion Kit (Lexogen, Greenland, NH, USA). cDNA library was then prepared using Swift Rapid RNA Library kit using the manufacturer's protocol (Swift Biosciences, Ann Arbor, MI, USA). The final quality control of the prepared library was done using Kapa qPCR and Agilent Tapestation 4150 (Agilent Technologies, Santa Clara, CA, USA). The library was sequenced using the Illumina-NovaSeq platform using an S4 flow cell with a 150-bp paired-end module. Approximately 20 million reads (10 million in each direction) were generated per sample. All the samples were used as biological triplicates for statistical validation.

\subsection{QC of Raw RNA Sequencing Reads and Data Analysis}

To ensure the quality of subsequent data analysis, the raw RNA-seq reads were subjected to quality control using FASTQC tool that generated average Q scores across the length of all sequence files [93]. The data obtained after initial QC was processed using Trimmomatic (version 0.38) [94]. An illuminaclip step was used to remove adapter 
sequences (TruSeq3 pair ended) from the reads. The raw reads were further filtered using a sliding window filtration to truncate reads at a 4-base average Q score of 20 or lower. The sequences greater than $20 \mathrm{bp}$ were retained. The QC reads were then mapped against DAG20 reference genome (accession PRJNA329) using the HISAT2 alignment program [95]. The number of reads mapping to each gene was counted using DA-G20 genome annotation file (GFF3, Ensembl) and read summarization program: featureCounts [96]. The gene expression fold change was estimated amongst various sample groups $(0 \mu \mathrm{M}$ vs. $5 \mu \mathrm{M}$ $\mathrm{Cu}(\mathrm{II}), 0 \mu \mathrm{M}$ vs. $15 \mu \mathrm{M} \mathrm{Cu}(\mathrm{II}), 5 \mu \mathrm{M}$ vs. $15 \mu \mathrm{M} \mathrm{Cu}(\mathrm{II}))$ using the DESeq2 package [26]. DeSeq2 uses the median of ratios normalization for differential gene expression analysis between samples. The data analysis (until DESeq2) was done using the web-based scientific analysis platform Galaxy [97].

\subsection{RT-qPCR Validation}

Some differentially expressed genes were randomly selected for RT-qPCR analysis to validate the quality of sequencing data. RNA was extracted and purified as described in the previous section on RNA isolation. cDNA synthesis was performed using the QuantiTect Reverse Transcription Kit (Qiagen, Germantown, MD, USA). Subsequently, RTqPCR was performed in a QuantStudio 3 real-time PCR system (Thermo Fisher Scientific, Waltham, MA, USA) using the Maxima SYBR Green/ROX qPCR Master Mix (Thermo Fisher Scientific, Waltham, MA, USA) in a 96-well plate. Gene-specific primers used for RT-qPCR are shown in Table S2. Recombinase A (recA) was used as an internal gene standard for PCR amplification and data normalization. Normalized fold changes of the relative expression ratio between control and $\mathrm{Cu}(\mathrm{II})$ spiked samples were quantified by the $2^{-\Delta \Delta C T}$ method [98]. All experiments were performed in triplicate using independent samples, and their mean value and standard error of the mean were calculated.

\subsection{Network Analysis Using Cytoscape}

The STRING database that integrates both known and predicted protein-protein interactions (PPIs) was used to predict functional interactions of proteins [99]. The PPI network between the significant DEGs ( $p$-value $<0.05)$ was visualized using the PPI visualization software Cytoscape (version-3.9.0) [100]. DA-G20 was selected as the organism, and a confidence score cutoff of greater than 0.40 was used to find top interactors. Highly connected regions of the network were detected using ClusterONE (version 1.0) [101] algorithm with the following criteria: minimum size $=5$, minimum density $=0.05$, and edge weights = combined score. StringApp (Cytoscape plugin) was used to perform pathway enrichment analysis and import PPI networks from the STRING database to Cytoscape [102]. The most enriched gene set was selected based on a false discovery rate of $1.0 \times 10^{-6}$. The most enriched pathway was selected for analyzing the interaction network, and a doughnut graph was assigned to each of the nodes with upregulated and downregulated $\log _{2} \mathrm{FC}$ values. In the PPI network, the nodes correspond to the proteins, and the edges represent the interactions.

\subsection{Bioinformatics Analysis}

Significantly differentially expressed genes ( $p$-value $<0.05)$ were annotated with the respective proteins using the UniProt database [103]. The differentially expressed genes were further subcategorized based on their gene ontology terms (biological process, molecular functions, and cellular component) and pathways using the Quick GO database and BioCyc pathway/genome database collection [104,105]. R statistical programming language was used for computational analysis and generation of figures.

\subsection{Targeted Metabolomics Analysis}

Targeted metabolomics analysis was performed on $0 \mu \mathrm{M}, 5 \mu \mathrm{M}$, and $15 \mu \mathrm{M} \mathrm{Cu}$ (II) by sending samples to the Metabolomics lab at the University of Illinois, Urbana Champaign, USA. The detailed procedure is outlined in the study by Gomez et al. [106]. Briefly, 
metabolites were extracted with $1 \mathrm{~mL}$ of $70 \%$ methanol and sonicated using an ultrasonic homogenizer. The lysed cell pellets thus obtained were fractionated with $70 \%$ methanol and chloroform and finally centrifuged for $10 \mathrm{~min}$ at maximum speed. One $\mathrm{mL}$ of each extract was evaporated under vacuum at $-60{ }^{\circ} \mathrm{C}$, and dried extracts were derivatized. Five microliters $(5 \mu \mathrm{L})$ of the internal standard (hentriacontanoic acid $(10 \mathrm{mg} / \mathrm{mL})$; SigmaAldrich, St. Louis, MO, USA) was added to each sample prior to derivatization, and all the samples were analyzed on a GC/MS system (Agilent Technologies, Santa Clara, CA, USA) consisting of an Agilent 7890 gas chromatograph, an Agilent 5975 mass selective detector, and an HP 7683B autosampler.

All the chromatogram peaks (spectra) were compared with electron impact mass spectrum libraries NIST08 (NIST, Gaithersburg, MD, USA), W8N08 (Palisade Corporation, Ithaca, NY, USA), and a custom-built library of 520 unique metabolites [106]. The data obtained were normalized to the internal standard in each chromatogram and the sample dry weight (DW). AMDIS 2.71 (NIST, Gaithersburg, MD, USA) was used to evaluate the spectra of all chromatogram peaks. All metabolite concentrations are reported as relative concentration, i.e., 'analyte concentration relative to hentriacontanoic acid per gram dry weight (for cell pellets) or per $\mathrm{mL}$ (for supernatant)'. More details on GC/MS data transformation are provided in the Supplementary Information.

\section{Conclusions}

The introduction of $\mathrm{Cu}(\mathrm{II})$ stress to DA-G20 caused common heavy-metal-associated oxidative stress as well as effects that seem to be exclusive during $\mathrm{Cu}(\mathrm{II})$ exposure. The most common effects observed in this study were: (i) energy conservation through translation arrest; (ii) downregulation of chemotaxis and motility; (iii) differential expression of certain transporter systems and inorganic ion transport complexes; (iv) upregulation of sigma factor proteins; and (v) the increased production of organic acids and amino acids. In addition, $\mathrm{Cu}$ (II) stress was found to disrupt the homeostasis of other heavy metals such as iron and zinc. Furthermore, DA-G20 was able to detoxify $\mathrm{Cu}(\mathrm{II})$ ions through four different strategies: (i) prevention of metal ions from entering the cells through the downregulation of several inorganic ion transporter complexes; (ii) the active transport of the metal ions out of the cell through the up-regulation of specific transporter complexes; (iii) intracellular sequestration of the $\mathrm{Cu}(\mathrm{II})$ ions by proteins rich in peptides with specific metal-binding amino acids; and (iv) through synthesis of specific metabolites that resulted in altering the cellular metal buffering system to prevent oxidative damage. The observed responses and differential gene expression in this study were primarily caused by the secondary effects of general heavy-metal toxicity. Some changes such as upregulation of ApbE family lipoprotein observed in this study seem to be specific for DA-G20 exposed to $\mathrm{Cu}(\mathrm{II})$ ions. However, further research is required to elucidate the underlying signaling processes involved in $\mathrm{Cu}$ (II) stress-response management. Our findings provide a framework for further research on the mechanism of $\mathrm{Cu}$ (II) toxicity in DA-G20. However, $\mathrm{Cu}(\mathrm{II})$ stress response seems to be a complex process that includes various regulatory processes. Integrated transcriptomic, metabolomics and proteomic analysis of DA-G20 will be necessary to validate the roles of identified genes during $\mathrm{Cu}(\mathrm{II})$ stress.

Supplementary Materials: The following supporting information can be downloaded at: https:// www.mdpi.com/article/10.3390/ijms23031396/s1.

Author Contributions: Conceptualization, A.K.T., P.S. and R.K.S.; methodology, A.K.T. and P.S.; software, A.K.T., P.S. and D.S.; validation, P.T., S.R., D.S., V.G., R.N.S. and R.K.S.; formal analysis, A.K.T. and P.S.; investigation, A.K.T.; data curation, A.K.T.; writing-original draft preparation, A.K.T.; writing—review and editing, A.K.T., P.S., P.T., S.R., V.G., D.S., R.N.S. and R.K.S.; visualization, A.K.T.; supervision, R.K.S.; project administration, R.K.S.; funding acquisition, R.K.S. All authors have read and agreed to the published version of the manuscript. 
Funding: We gratefully acknowledge support from the National Science Foundation (Awards \#1736255, \#1849206, and \#1920954) and the Department of Chemical and Biological Engineering at the South Dakota School of Mines and Technology.

Institutional Review Board Statement: Not applicable.

Informed Consent Statement: Not applicable.

Data Availability Statement: The sequences were uploaded and deposited in the National Center for Biotechnology Information (NCBI) Gene Expression Omnibus (GEO) under the accession number GSE191076.

Conflicts of Interest: The authors declare no conflict of interest. The funders had no role in the design of the study; in the collection, analyses, or interpretation of data; in the writing of the manuscript or in the decision to publish the results.

\section{References}

1. Giachino, A.; Waldron, K.J. Copper tolerance in bacteria requires the activation of multiple accessory pathways. Mol. Microbiol. 2020, 114, 377-390. [CrossRef] [PubMed]

2. Salah, I.; Parkin, I.P.; Allan, E. Copper as an antimicrobial agent: Recent advances. RSC Adv. 2021, 11, 18179-18186. [CrossRef]

3. Oursel, B.; Garnier, C.; Durrieu, G.; Mounier, S.; Omanović, D.; Lucas, Y. Dynamics and fates of trace metals chronically input in a Mediterranean coastal zone impacted by a large urban area. Mar. Pollut. Bull. 2013, 69, 137-149. [CrossRef] [PubMed]

4. Sani Rajesh, K.; Peyton Brent, M.; Brown Laura, T. Copper-Induced Inhibition of Growth of Desulfovibrio desulfuricans G20: Assessment of Its Toxicity and Correlation with Those of Zinc and Lead. Appl. Environ. Microbiol. 2001, 67, 4765-4772. [CrossRef] [PubMed]

5. Tchounwou, P.B.; Yedjou, C.G.; Patlolla, A.K.; Sutton, D.J. Heavy metal toxicity and the environment. Exp. Suppl. 2012, 101, 133-164. [CrossRef]

6. Vargas, I.T.; Fischer, D.A.; Alsina, M.A.; Pavissich, J.P.; Pastén, P.A.; Pizarro, G.E. Copper Corrosion and Biocorrosion Events in Premise Plumbing. Materials 2017, 10, 1036. [CrossRef]

7. Taylor, A.A.; Tsuji, J.S.; Garry, M.R.; McArdle, M.E.; Goodfellow, W.L.; Adams, W.J.; Menzie, C.A. Critical Review of Exposure and Effects: Implications for Setting Regulatory Health Criteria for Ingested Copper. Environ. Manag. 2020, 65, 131-159. [CrossRef]

8. Verma, S.; Kuila, A. Bioremediation of heavy metals by microbial process. Environ. Technol. Innov. 2019, 14, 100369. [CrossRef]

9. Andreini, C.; Banci, L.; Bertini, I.; Rosato, A. Occurrence of Copper Proteins through the Three Domains of Life: A Bioinformatic Approach. J. Proteome Res. 2008, 7, 209-216. [CrossRef]

10. Arguello, J.; Raimunda, D.; Padilla-Benavides, T. Mechanisms of copper homeostasis in bacteria. Front. Cell. Infect. Microbiol. 2013, 3, 73. [CrossRef]

11. Rensing, C.; Grass, G. Escherichia coli mechanisms of copper homeostasis in a changing environment. FEMS Microbiol. Rev. 2003, 27, 197-213. [CrossRef]

12. Bhamidimarri, S.P.; Young, T.R.; Shanmugam, M.; Soderholm, S.; Baslé, A.; Bumann, D.; van den Berg, B. Acquisition of ionic copper by the bacterial outer membrane protein OprC through a novel binding site. PLoS Biol. 2021, 19, e3001446. [CrossRef] [PubMed]

13. Barwinska-Sendra, A.; Waldron, K.J. The Role of Intermetal Competition and Mis-Metalation in Metal Toxicity. Adv. Microb. Physiol. 2017, 70, 315-379. [CrossRef] [PubMed]

14. Dupont, C.L.; Grass, G.; Rensing, C. Copper toxicity and the origin of bacterial resistance-New insights and applications. Metallomics 2011, 3, 1109-1118. [CrossRef] [PubMed]

15. Raimunda, D.; González-Guerrero, M.; Leeber, B.W., 3rd; Argüello, J.M. The transport mechanism of bacterial Cu+-ATPases: Distinct efflux rates adapted to different function. Biometals 2011, 24, 467-475. [CrossRef]

16. Jiang, W.; Fan, W. Bioremediation of heavy metal-contaminated soils by sulfate-reducing bacteria. Ann. N. Y. Acad. Sci. 2008, 1140, 446-454. [CrossRef]

17. Hussain, A.; Hasan, A.; Javid, A.; Qazi, J.I. Exploited application of sulfate-reducing bacteria for concomitant treatment of metallic and non-metallic wastes: A mini review. 3 Biotech 2016, 6, 119. [CrossRef]

18. Sani, R.K.; Geesey, G.G.; Peyton, B.M. Assessment of lead toxicity to Desulfovibrio desulfuricans G20: Influence of components of lactate C medium. Adv. Environ. Res. 2001, 5, 269-276. [CrossRef]

19. Tripathi, A.K.; Thakur, P.; Saxena, P.; Rauniyar, S.; Gopalakrishnan, V.; Singh, R.N.; Gadhamshetty, V.; Gnimpieba, E.Z.; Jasthi, B.K.; Sani, R.K. Gene Sets and Mechanisms of Sulfate-Reducing Bacteria Biofilm Formation and Quorum Sensing with Impact on Corrosion. Front. Microbiol. 2021, 12, 3120. [CrossRef]

20. Ayangbenro, A.S.; Olanrewaju, O.S.; Babalola, O.O. Sulfate-Reducing Bacteria as an Effective Tool for Sustainable Acid Mine Bioremediation. Front. Microbiol. 2018, 9, 1986. [CrossRef]

21. Miran, W.; Jang, J.; Nawaz, M.; Shahzad, A.; Jeong, S.E.; Jeon, C.O.; Lee, D.S. Mixed sulfate-reducing bacteria-enriched microbial fuel cells for the treatment of wastewater containing copper. Chemosphere 2017, 189, 134-142. [CrossRef] [PubMed] 
22. Jalali, K.; Baldwin, S.A. The role of sulphate reducing bacteria in copper removal from aqueous sulphate solutions. Water Res. 2000, 34, 797-806. [CrossRef]

23. Andrei, A.; Öztürk, Y.; Khalfaoui-Hassani, B.; Rauch, J.; Marckmann, D.; Trasnea, P.-I.; Daldal, F.; Koch, H.-G. Cu Homeostasis in Bacteria: The Ins and Outs. Membranes 2020, 10, 242. [CrossRef] [PubMed]

24. Monds, R.D.; Lee, T.K.; Colavin, A.; Ursell, T.; Quan, S.; Cooper, T.F.; Huang, K.C. Systematic perturbation of cytoskeletal function reveals a linear scaling relationship between cell geometry and fitness. Cell Rep. 2014, 9, 1528-1537. [CrossRef] [PubMed]

25. Geiler-Samerotte, K.A.; Li, S.; Lazaris, C.; Taylor, A.; Ziv, N.; Ramjeawan, C.; Paaby, A.B.; Siegal, M.L. Extent and context dependence of pleiotropy revealed by high-throughput single-cell phenotyping. PLoS Biol. 2020, 18, e3000836. [CrossRef]

26. Love, M.I.; Huber, W.; Anders, S. Moderated estimation of fold change and dispersion for RNA-seq data with DESeq2. Genome Biol. 2014, 15, 550. [CrossRef]

27. Petit-Härtlein, I.; Rome, K.; de Rosny, E.; Molton, F.; Duboc, C.; Gueguen, E.; Rodrigue, A.; Covès, J. Biophysical and physiological characterization of ZraP from Escherichia coli, the periplasmic accessory protein of the atypical ZraSR two-component system. Biochem. J. 2015, 472, 205-216. [CrossRef]

28. Adhikari, S.; Curtis, P.D. DNA methyltransferases and epigenetic regulation in bacteria. FEMS Microbiol. Rev. 2016, 40, 575-591. [CrossRef]

29. Barton, L.L.; Goulhen, F.; Bruschi, M.; Woodards, N.A.; Plunkett, R.M.; Rietmeijer, F.J.M. The bacterial metallome: Composition and stability with specific reference to the anaerobic bacterium Desulfovibrio desulfuricans. BioMetals 2007, 20, 291-302. [CrossRef]

30. Walter, W.; Sánchez-Cabo, F.; Ricote, M. GOplot: An R package for visually combining expression data with functional analysis. Bioinformatics 2015, 31, 2912-2914. [CrossRef]

31. Galperin, M.Y.; Nikolskaya, A.N.; Koonin, E.V. Novel domains of the prokaryotic two-component signal transduction systems FEMS Microbiol. Lett. 2001, 203, 11-21. [CrossRef] [PubMed]

32. Ruiz, N. Lipid Flippases for Bacterial Peptidoglycan Biosynthesis. Lipid Insights 2015, 8 (Suppl. S1), 21-31. [CrossRef] [PubMed]

33. Prabhakaran, P.; Ashraf, M.A.; Aqma, W.S. Microbial stress response to heavy metals in the environment. RSC Adv. 2016, 6 , 109862-109877. [CrossRef]

34. Pal, A.; Bhattacharjee, S.; Saha, J.; Sarkar, M.; Mandal, P. Bacterial survival strategies and responses under heavy metal stress: A comprehensive overview. Crit. Rev. Microbiol. 2021, 48, 1-29. [CrossRef]

35. Plugge, C.; Zhang, W.; Scholten, J.; Stams, A. Metabolic Flexibility of Sulfate-Reducing Bacteria. Front. Microbiol. 2011, 2, 81. [CrossRef]

36. Joudeh, N.; Saragliadis, A.; Schulz, C.; Voigt, A.; Almaas, E.; Linke, D. Transcriptomic Response Analysis of Escherichia coli to Palladium Stress. Front. Microbiol. 2021, 12, 2840. [CrossRef]

37. Hu, P.; Brodie Eoin, L.; Suzuki, Y.; McAdams Harley, H.; Andersen Gary, L. Whole-Genome Transcriptional Analysis of Heavy Metal Stresses in Caulobacter crescentus. J. Bacteriol. 2005, 187, 8437-8449. [CrossRef]

38. Volpicella, M.; Leoni, C.; Manzari, C.; Chiara, M.; Picardi, E.; Piancone, E.; Italiano, F.; D’Erchia, A.; Trotta, M.; Horner, D.S.; et al. Transcriptomic analysis of nickel exposure in Sphingobium sp. ba1 cells using RNA-seq. Sci. Rep. 2017, 7, 8262. [CrossRef]

39. Kershaw, C.J.; Brown, N.L.; Constantinidou, C.; Patel, M.D.; Hobman, J.L. The expression profile of Escherichia coli K-12 in response to minimal, optimal and excess copper concentrations. Microbiology 2005, 151 Pt 4, 1187-1198. [CrossRef]

40. Pontes, M.H.; Sevostyanova, A.; Groisman, E.A. When Too Much ATP Is Bad for Protein Synthesis. J. Mol. Biol. 2015, 427, 2586-2594. [CrossRef]

41. Wang, A.; Crowley, D.E. Global gene expression responses to cadmium toxicity in Escherichia coli. J. Bacteriol. 2005, 187, 3259-3266. [CrossRef] [PubMed]

42. Gault, M.; Effantin, G.; Rodrigue, A. Ni exposure impacts the pool of free Fe and modifies DNA supercoiling via metal-induced oxidative stress in Escherichia coli K-12. Free Radic. Biol. Med. 2016, 97, 351-361. [CrossRef] [PubMed]

43. McQuillan, J.S.; Shaw, A.M. Differential gene regulation in the Ag nanoparticle and $\mathrm{Ag}(+)$-induced silver stress response in Escherichia coli: A full transcriptomic profile. Nanotoxicology 2014, 8 (Suppl. S1), 177-184. [CrossRef] [PubMed]

44. Polikanov, Y.S.; Aleksashin, N.A.; Beckert, B.; Wilson, D.N. The Mechanisms of Action of Ribosome-Targeting Peptide Antibiotics. Front. Mol. Biosci. 2018, 5, 48. [CrossRef]

45. Piepenbreier, H.; Fritz, G.; Gebhard, S. Transporters as information processors in bacterial signalling pathways. Mol. Microbiol. 2017, 104, 1-15. [CrossRef]

46. Porcheron, G.; Garenaux, A.; Proulx, J.; Sabri, M.; Dozois, C. Iron, copper, zinc, and manganese transport and regulation in pathogenic Enterobacteria: Correlations between strains, site of infection and the relative importance of the different metal transport systems for virulence. Front. Cell. Infect. Microbiol. 2013, 3, 90. [CrossRef]

47. El-Awady, R.; Saleh, E.; Hashim, A.; Soliman, N.; Dallah, A.; Elrasheed, A.; Elakraa, G. The Role of Eukaryotic and Prokaryotic ABC Transporter Family in Failure of Chemotherapy. Front. Pharmacol. 2017, 7, 535. [CrossRef]

48. Herrou, J.; Willett, J.W.; Czyż, D.M.; Babnigg, G.; Kim, Y.; Crosson, S. Conserved ABC Transport System Regulated by the General Stress Response Pathways of Alpha- and Gammaproteobacteria. J. Bacteriol. 2017, 199, e00746-16. [CrossRef]

49. Ayangbenro, A.S.; Babalola, O.O. A New Strategy for Heavy Metal Polluted Environments: A Review of Microbial Biosorbents. Int. J. Environ. Res. Public Health 2017, 14, 94. [CrossRef]

50. Biemans-Oldehinkel, E.; Mahmood, N.A.B.N.; Poolman, B. A sensor for intracellular ionic strength. Proc. Natl. Acad. Sci. USA 2006, 103, 10624-10629. [CrossRef] 
51. Fantino, J.R.; Py, B.; Fontecave, M.; Barras, F. A genetic analysis of the response of Escherichia coli to cobalt stress. Environ. Microbiol. 2010, 12, 2846-2857. [CrossRef] [PubMed]

52. LaVoie, S.P.; Summers, A.O. Correction to: Transcriptional responses of Escherichia coli during recovery from inorganic or organic mercury exposure. BMC Genom. 2018, 19, 268. [CrossRef] [PubMed]

53. Ma, Z.; Jacobsen, F.E.; Giedroc, D.P. Coordination chemistry of bacterial metal transport and sensing. Chem. Rev. 2009, 109, 4644-4681. [CrossRef] [PubMed]

54. Nies, D.H. Efflux-mediated heavy metal resistance in prokaryotes. FEMS Microbiol. Rev. 2003, 27, 313-339. [CrossRef]

55. Chien, C.C.; Huang, C.H.; Lin, Y.W. Characterization of a heavy metal translocating P-type ATPase gene from an environmental heavy metal resistance Enterobacter sp. isolate. Appl. Biochem. Biotechnol. 2013, 169, 1837-1846. [CrossRef] [PubMed]

56. Valencia, E.Y.; Braz, V.S.; Guzzo, C.; Marques, M.V. Two RND proteins involved in heavy metal efflux in Caulobacter crescentus belong to separate clusters within proteobacteria. BMC Microbiol. 2013, 13, 79. [CrossRef]

57. Chandrangsu, P.; Rensing, C.; Helmann, J.D. Metal homeostasis and resistance in bacteria. Nat. Rev. Microbiol. 2017, 15, 338-350. [CrossRef]

58. Lewinson, O.; Lee, A.T.; Rees, D.C. A P-type ATPase importer that discriminates between essential and toxic transition metals Proc. Natl. Acad. Sci. USA 2009, 106, 4677. [CrossRef]

59. Rolfe, R.D.; Hentges, D.J.; Campbell, B.J.; Barrett, J.T. Factors related to the oxygen tolerance of anaerobic bacteria. Appl. Environ. Microbiol. 1978, 36, 306-313. [CrossRef]

60. Rocha, E.R.; Selby, T.; Coleman, J.P.; Smith, C.J. Oxidative stress response in an anaerobe, Bacteroides fragilis: A role for catalase in protection against hydrogen peroxide. J. Bacteriol. 1996, 178, 6895-6903. [CrossRef]

61. Ray, P.D.; Huang, B.W.; Tsuji, Y. Reactive oxygen species (ROS) homeostasis and redox regulation in cellular signaling. Cell. Signal. 2012, 24, 981-990. [CrossRef] [PubMed]

62. Colvin, R.A.; Holmes, W.R.; Fontaine, C.P.; Maret, W. Cytosolic zinc buffering and muffling: Their role in intracellular zinc homeostasis. Metallomics 2010, 2, 306-317. [CrossRef] [PubMed]

63. Krishna Deepak, R.N.V.; Chandrakar, B.; Sankararamakrishnan, R. Comparison of metal-binding strength between methionine and cysteine residues: Implications for the design of metal-binding motifs in proteins. Biophys. Chem. 2017, 224, 32-39. [CrossRef]

64. Lee, L.J.; Barrett, J.A.; Poole, R.K. Genome-wide transcriptional response of chemostat-cultured Escherichia coli to zinc. J. Bacteriol. 2005, 187, 1124-1134. [CrossRef] [PubMed]

65. Hoostal, M.J.; Bidart-Bouzat, M.G.; Bouzat, J.L. Local adaptation of microbial communities to heavy metal stress in polluted sediments of Lake Erie. FEMS Microbiol. Ecol. 2008, 65, 156-168. [CrossRef]

66. Uda, N.R.; Upert, G.; Angelici, G.; Nicolet, S.; Schmidt, T.; Schwede, T.; Creus, M. Zinc-selective inhibition of the promiscuous bacterial amide-hydrolase DapE: Implications of metal heterogeneity for evolution and antibiotic drug design. Metallomics 2014, 6, 88-95. [CrossRef]

67. Jaworska, H.; Lemanowicz, J. Heavy metal contents and enzymatic activity in soils exposed to the impact of road traffic. Sci. Rep. 2019, 9, 19981. [CrossRef]

68. Wadhams, G.H.; Armitage, J.P. Making sense of it all: Bacterial chemotaxis. Nat. Rev. Mol. Cell Biol. 2004, 5, 1024-1037. [CrossRef]

69. Singh, K.; Senadheera, D.B.; Cvitkovitch, D.G. An intimate link: Two-component signal transduction systems and metal transport systems in bacteria. Future Microbiol. 2014, 9, 1283-1293. [CrossRef]

70. Berg, H.C. The Rotary Motor of Bacterial Flagella. Annu. Rev. Biochem. 2003, 72, 19-54. [CrossRef]

71. Yung, M.C.; Ma, J.; Salemi, M.R.; Phinney, B.S.; Bowman, G.R.; Jiao, Y. Shotgun Proteomic Analysis Unveils Survival and Detoxification Strategies by Caulobacter crescentus during Exposure to Uranium, Chromium, and Cadmium. J. Proteome Res. 2014, 13, 1833-1847. [CrossRef] [PubMed]

72. Chourey, K.; Thompson, M.R.; Morrell-Falvey, J.; Verberkmoes, N.C.; Brown, S.D.; Shah, M.; Zhou, J.; Doktycz, M.; Hettich, R.L.; Thompson, D.K. Global molecular and morphological effects of 24-hour chromium(VI) exposure on Shewanella oneidensis MR-1. Appl. Environ. Microbiol. 2006, 72, 6331-6344. [CrossRef] [PubMed]

73. Johansen, J.; Eriksen, M.; Kallipolitis, B.; Valentin-Hansen, P. Down-regulation of outer membrane proteins by noncoding RNAs: Unraveling the cAMP-CRP- and sigmaE-dependent CyaR-ompX regulatory case. J. Mol. Biol. 2008, 383, 1-9. [CrossRef] [PubMed]

74. Zschiedrich, C.P.; Keidel, V.; Szurmant, H. Molecular Mechanisms of Two-Component Signal Transduction. J. Mol. Biol. 2016, 428, 3752-3775. [CrossRef] [PubMed]

75. Beck, B.J.; Downs, D.M. The apbE gene encodes a lipoprotein involved in thiamine synthesis in Salmonella typhimurium. J. Bacteriol. 1998, 180, 885-891. [CrossRef] [PubMed]

76. Beck, B.J.; Downs, D.M. A periplasmic location is essential for the role of the ApbE lipoprotein in thiamine synthesis in Salmonella typhimurium. J. Bacteriol. 1999, 181, 7285-7290. [CrossRef]

77. Skovran, E.; Downs, D.M. Lack of the ApbC or ApbE protein results in a defect in Fe-S cluster metabolism in Salmonella enterica serovar Typhimurium. J. Bacteriol. 2003, 185, 98-106. [CrossRef]

78. Bertsova, Y.V.; Fadeeva, M.S.; Kostyrko, V.A.; Serebryakova, M.V.; Baykov, A.A.; Bogachev, A.V. Alternative pyrimidine biosynthesis protein ApbE is a flavin transferase catalyzing covalent attachment of FMN to a threonine residue in bacterial flavoproteins. J. Biol. Chem. 2013, 288, 14276-14286. [CrossRef]

79. Helbig, K.; Grosse, C.; Nies, D.H. Cadmium toxicity in glutathione mutants of Escherichia coli. J. Bacteriol. 2008, 190, 5439-5454. [CrossRef] 
80. Zhang, Y.; Chen, S.; Hao, X.; Su, J.Q.; Xue, X.; Yan, Y.; Zhu, Y.G.; Ye, J. Transcriptomic Analysis Reveals Adaptive Responses of an Enterobacteriaceae Strain LSJC7 to Arsenic Exposure. Front. Microbiol. 2016, 7, 636. [CrossRef]

81. Górecka, K.M.; Krepl, M.; Szlachcic, A.; Poznański, J.; Šponer, J.; Nowotny, M. RuvC uses dynamic probing of the Holliday junction to achieve sequence specificity and efficient resolution. Nat. Commun. 2019, 10, 4102. [CrossRef] [PubMed]

82. Gunderson, C.W.; Segall, A.M. DNA repair, a novel antibacterial target: Holliday junction-trapping peptides induce DNA damage and chromosome segregation defects. Mol. Microbiol. 2006, 59, 1129-1148. [CrossRef] [PubMed]

83. Casadesús, J.; Low, D. Epigenetic gene regulation in the bacterial world. Microbiol. Mol. Biol. Rev. MMBR 2006, 70, 830-856. [CrossRef] [PubMed]

84. Blow, M.J.; Clark, T.A.; Daum, C.G.; Deutschbauer, A.M.; Fomenkov, A.; Fries, R.; Froula, J.; Kang, D.D.; Malmstrom, R.R.; Morgan, R.D.; et al. The Epigenomic Landscape of Prokaryotes. PLoS Genet. 2016, 12, e1005854. [CrossRef] [PubMed]

85. Bendall, M.L.; Luong, K.; Wetmore, K.M.; Blow, M.; Korlach, J.; Deutschbauer, A.; Malmstrom, R.R. Exploring the Roles of DNA Methylation in the Metal-Reducing Bacterium Shewanella oneidensis MR-1. J. Bacteriol. 2013, 195, 4966-4974. [CrossRef]

86. Ruiz, N. Bioinformatics identification of MurJ (MviN) as the peptidoglycan lipid II flippase in Escherichia coli. Proc. Natl. Acad. Sci. USA 2008, 105, 15553-15557. [CrossRef]

87. Erickson Harold, P.; Anderson David, E.; Osawa, M. FtsZ in Bacterial Cytokinesis: Cytoskeleton and Force Generator All in One. Microbiol. Mol. Biol. Rev. 2010, 74, 504-528. [CrossRef]

88. Chien, A.C.; Hill, N.S.; Levin, P.A. Cell size control in bacteria. Curr. Biol. 2012, 22, R340-R349. [CrossRef]

89. Palacios, P.; Vicente, M.; Sánchez, M. Dependency of Escherichia coli cell-division size, and independency of nucleoid segregation on the mode and level of ftsZ expression. Mol. Microbiol. 1996, 20, 1093-1098. [CrossRef]

90. Bach, J.N.; Albrecht, N.; Bramkamp, M. Imaging DivIVA dynamics using photo-convertible and activatable fluorophores in Bacillus subtilis. Front. Microbiol. 2014, 5, 59. [CrossRef]

91. Wu, L.; Wang, Y.; Zhou, S.; Zhu, Y.; Chen, X. Enzyme-induced $\mathrm{Cu}^{2+} / \mathrm{Cu}^{+}$conversion as the electrochemical signal for sensitive detection of ethyl carbamate. Anal. Chim. Acta 2021, 1151, 338256. [CrossRef] [PubMed]

92. Rio, D.C.; Ares, M., Jr.; Hannon, G.J.; Nilsen, T.W. Purification of RNA using TRIzol (TRI reagent). Cold Spring Harb. Protoc. 2010, 2010, pdb.prot5439. [CrossRef] [PubMed]

93. Andrews, S. FASTQC. A Quality Control Tool for High Throughput Sequence Data. 2010. Available online: https://www. bioinformatics.babraham.ac.uk/projects/fastqc/ (accessed on 23 December 2020).

94. Bolger, A.M.; Lohse, M.; Usadel, B. Trimmomatic: A flexible trimmer for Illumina sequence data. Bioinformatics 2014, 30, 2114-2120. [CrossRef] [PubMed]

95. Kim, D.; Paggi, J.M.; Park, C.; Bennett, C.; Salzberg, S.L. Graph-based genome alignment and genotyping with HISAT2 and HISAT-genotype. Nat. Biotechnol. 2019, 37, 907-915. [CrossRef]

96. Liao, Y.; Smyth, G.K.; Shi, W. featureCounts: An efficient general purpose program for assigning sequence reads to genomic features. Bioinformatics 2013, 30, 923-930. [CrossRef]

97. Afgan, E.; Baker, D.; Batut, B.; van den Beek, M.; Bouvier, D.; Čech, M.; Chilton, J.; Clements, D.; Coraor, N.; Grüning, B.A.; et al. The Galaxy platform for accessible, reproducible and collaborative biomedical analyses: 2018 update. Nucleic Acids Res. 2018, 46, W537-W544. [CrossRef]

98. Livak, K.J.; Schmittgen, T.D. Analysis of relative gene expression data using real-time quantitative PCR and the 2(-Delta Delta C(T)) Method. Methods 2001, 25, 402-408. [CrossRef]

99. Szklarczyk, D.; Franceschini, A.; Wyder, S.; Forslund, K.; Heller, D.; Huerta-Cepas, J.; Simonovic, M.; Roth, A.; Santos, A.; Tsafou, K.P.; et al. STRING v10: Protein-protein interaction networks, integrated over the tree of life. Nucleic Acids Res. 2015, 43, D447-D452. [CrossRef]

100. Shannon, P.; Markiel, A.; Ozier, O.; Baliga, N.S.; Wang, J.T.; Ramage, D.; Amin, N.; Schwikowski, B.; Ideker, T. Cytoscape: A software environment for integrated models of biomolecular interaction networks. Genome Res. 2003, 13, 2498-2504. [CrossRef]

101. Nepusz, T.; Yu, H.; Paccanaro, A. Detecting overlapping protein complexes in protein-protein interaction networks. Nat. Methods 2012, 9, 471-472. [CrossRef]

102. Doncheva, N.T.; Morris, J.H.; Gorodkin, J.; Jensen, L.J. Cytoscape StringApp: Network Analysis and Visualization of Proteomics Data. J. Proteome Res. 2019, 18, 623-632. [CrossRef] [PubMed]

103. Consortium, T.U. UniProt: The universal protein knowledgebase in 2021. Nucleic Acids Res. 2020, 49, D480-D489. [CrossRef] [PubMed]

104. Binns, D.; Dimmer, E.; Huntley, R.; Barrell, D.; O’Donovan, C.; Apweiler, R. QuickGO: A web-based tool for Gene Ontology searching. Bioinformatics 2009, 25, 3045-3046. [CrossRef] [PubMed]

105. Karp, P.D.; Billington, R.; Caspi, R.; Fulcher, C.A.; Latendresse, M.; Kothari, A.; Keseler, I.M.; Krummenacker, M.; Midford, P.E.; Ong, Q.; et al. The BioCyc collection of microbial genomes and metabolic pathways. Brief Bioinform. 2019, 20, 1085-1093. [CrossRef] [PubMed]

106. Gomez, A.; Petrzelkova, K.; Yeoman, C.J.; Vlckova, K.; Mrázek, J.; Koppova, I.; Carbonero, F.; Ulanov, A.; Modry, D.; Todd, A.; et al. Gut microbiome composition and metabolomic profiles of wild western lowland gorillas (Gorilla gorilla gorilla) reflect host ecology. Mol. Ecol. 2015, 24, 2551-2565. [CrossRef] [PubMed] 